\title{
Review on DFT and ab initio Calculations of Scalar Coupling Constants
}

\author{
Ibon Alkorta* and José Elguero \\ Instituto de Química Médica, C.S.I.C., Juan de la Cierva, 3, E-28006 Madrid. \\ E-mail: ibon@iqm.csic.es, URL: http://www.iqm.csic.es/are/main.htm \\ * Authors to whom correspondence should be addressed. \\ Received: 24 May 2002 / Accepted: 17 July 2002 / Published: 25 February 2003
}

\begin{abstract}
The present review summarizes the information available on the $a b$ initio calculations of spin-spin nuclear coupling constants through hydrogen bonds or in van der Waals complexes. It also reports the sources of experimental data on ${ }^{\text {nh }} J_{X Y}$ scalar couplings.
\end{abstract}

Keywords: Coupling constants, supermolecules, hydrogen bonds, van der Waals complexes.

\section{Introduction}

We intend to summarize the present knowledge about the ab initio calculations of coupling constants in non bonded systems, also called supermolecules. Bonded means here, covalently bonded, because most supermolecules are formed by fragments linked together by hydrogen bonds (HBs). We will start with a brief summary of the theory of scalar coupling constants followed by the ab initio approach to these magnitudes. Then, the three main sections will be devoted to "Hydrogen bonded molecules: couplings through a hydrogen bond", to "Hydrogen bonded molecules: couplings through a dihydrogen bond" and to "Van der Waals complexes".

According to the IUPAC recommendations [1], ${ }^{\mathrm{n}} J$ should be used for nuclear spin-spin coupling constants through $\mathrm{n}$ bonds (usually given in frequency units) Parentheses may be used (for example) to indicate the species of nuclei coupled, e.g. $J\left({ }^{13} \mathrm{C},{ }^{1} \mathrm{H}\right)$ or, additionally, the coupling path, e.g. $J(\mathrm{POCF})$. Where no ambiguity arises, the elements involved can be, alternatively, given as subscripts, e.g. $J_{\mathrm{CH}}$. The nucleus of higher mass should be given first. ${ }^{\mathrm{n}} K$, is the reduced nuclear spin-spin coupling 
constant defined as $K_{\mathrm{jk}}=4 \pi^{2} J_{j k} / h \gamma_{j} \gamma_{\mathrm{k}}$, [2] where $h$ is the Planck constant and $\gamma_{1}, \gamma_{j}$ are the magnetogyric ratios of $i$ and $j$ nuclei (a list of $\gamma_{s}$ can be found in http://www.eclipse.net/ numare/nsinmrpt.htm). Reduced coupling constants are useful when comparing coupling constants for different isotopes. $K$ is given in $\mathrm{N} \mathrm{A}^{-2} \mathrm{~m}^{-3}$, the only problem is that due to the small value of $h\left(6.626176 \times 10^{-34} \mathrm{~J} \mathrm{~Hz}^{-1}\right), K$ is very large and usually given in $10^{19}$ to $10^{21}$ units. For instance, ${ }^{1} J_{\mathrm{CH}}$ in methane is equal to $125 \mathrm{~Hz}$, since $\gamma_{1 \mathrm{H}}=26.7510 * 10^{7}$ and $\gamma_{13 \mathrm{C}}=6.7283 * 10^{7} \mathrm{rad} \mathrm{T}^{-1} \mathrm{~s}^{-1},{ }^{1} K_{\mathrm{CH}}=4.141 * 10^{20} \mathrm{~N} \mathrm{~A}^{-2} \mathrm{~m}^{-3}$. The use of reduced coupling constants avoids some misunderstandings when comparing couplings between different nuclei, for instance, the fact that ${ }^{2 \mathrm{~h}} J_{\mathrm{NH}}(9 \mathrm{~Hz})$ is larger than ${ }^{1 \mathrm{~h}} J_{\mathrm{NN}}(3 \mathrm{~Hz})$ has been described as counterintuitive [3]. The corresponding reduced couplings are ${ }^{2 \mathrm{~h}} K_{\mathrm{NH}}=0.74 \cdot 10^{20}$ and ${ }^{1 \mathrm{~h}} K_{\mathrm{NN}}=2.43 \cdot$ $10^{20} \mathrm{~N} \mathrm{~A}^{-2} \mathrm{~m}^{-3}$.

Couplings through hydrogen bonds are usually named ${ }^{\text {nh }} J$ (other authors used ${ }^{\text {hn }} J$, a unification by the IUPAC of the notation seems highly desirable) where $\mathrm{h}$ stands for hydrogen bond and $\mathrm{n}$ is the number of bonds, including the HB, that separates the coupled nuclei.

\section{The theory of scalar spin-spin coupling constants}

Magnetic phenomena are included consistently in the Dirac relativistic equation. However, nonrelativistic limit (Pauli) is usually sufficient for interpretation of NMR experiments [4] if heavy atoms are excluded. Quantum mechanically, the scalar coupling can be defined as the mixed second derivative of the energy of the molecule with respect to the magnetic moments of two nuclei:

$$
J_{I S, x y}=\partial^{2} E / \partial \mu_{I, x} \partial \mu_{S, y}
$$

It can be subdivided into four distinct components:

- Fermi contact (FC), $H_{\mathrm{FC}}$.

- Paramagnetic spin-orbit (PSO), $H_{\mathrm{PSO}}$.

- Diamagnetic spin-orbit (DSO), $H_{\mathrm{DSO}}$.

- Spin-dipolar (SD), $H_{\mathrm{SD}}$.

$H=H_{\mathrm{FC}}+H_{\mathrm{PSO}}+H_{\mathrm{DSO}}+H_{\mathrm{SD}}$

In general, the most important contribution to the scalar coupling is the Fermi contact term, the exception being coupling constants involving fluorine atoms, in particular ${ }^{19} \mathrm{~F} \cdots{ }^{19} \mathrm{~F}$ couplings. This term relies on the probability of finding an electron at the site of the two coupled nuclei (this term rigorously disappears when there is no overlap between atoms). Concerning the FC term, it is expected that $\sigma$ electrons will play a very significant role since these are the only electrons that do not have nodes at the nuclear sites. Unlike $\pi$ or $\delta$ orbitals, only $\sigma$ orbitals have a nonzero value at the site of the nucleus. However, the FC coupling is also transmitted through the $\pi$-electronic system owing to 
exchange interactions between the $\sigma$ - and $\pi$-electronic systems (the FC spin information "leaks" into the p-electronic system). In fact, $\sigma$ orbitals are characterized by a cusp at the site of the nucleus. Thus, it can be seen that, unlike shielding, scalar coupling calculations will be specially sensitive to the shape of the electronic wavefunctions near the nucleus. This gives rise to the difficulty in using Gaussian functions; the problem stems from the difference between the cusp of a Gaussian orbital and that of an STO one. Thus, scalar coupling calculations are often much more demanding than chemical shifts.

In addition to the direct contact term (an electron actually visiting both nuclei), there is a magnetic interaction through space between the spin-orbit momentum of an electron and that of a nucleus. These two terms are very similar to the ones seen in defining shielding except that both sources of perturbation are nuclear magnetic moments (there is no external magnetic field). Many authors point out that there is a compensation between the PSO and DSO terms.

There is also the spin dipole-dipole interaction between electrons and nuclei. This interaction also does not require the Fermi-contact term. And lastly, there is a mixed Fermi contact, spin dipolar interaction where one interaction is between an electron visiting the site of one of the nuclei and interacting with the other nuclei through space. This interaction is primarily responsible for the observed anisotropy of the coupling tensor.

\section{$A b$ initio calculations of scalar coupling constants}

Concerning the examples found in the literature, they can be classified into three main groups:

1a. Methods based on DFT (Density Functional Theory).

Type DFT-FPT (Pople's Finite Perturbation Theory): Gaussian set of programs.

Type SOS (Sum-over-States)-DFPT (Density Finite Perturbation Theory): deMon Package (Salahub, Malkin, Malkina). This method only allows calculating the FC, PSO and DSO terms, not the SD term. Some authors, like Bartlett (see later on), stress that these methods are not recommended for atoms with lone pairs.

Type CPDTF-KS (Kohn-Sham operator) used by Cremer and Peralta [5,6].

2a. Methods based on MCSCF (Multiconfiguration Self Consistent Field): Dalton package (Ruud, Helgaker, see [7] for a detailed discussion about Hartree-Fock and post-Hartree-Fock calculations). 3a. Methods based on EOM (Equation of Motion)-CCSD (Coupled Cluster Singles and Doubles): ACES package (Gauss, Bartlett, Perera, del Bene).

To these methods correspond different types of functional and basis sets. Here are some representative examples:

1b. Functionals like VWN, PWP, B3PW91, B3LYP and their unrestricted versions and basis sets like IGLO-III, 6-311G**, 6-31G**.

2b. Basis sets like IGLO-III, aug-cc-pVDZ, etc.

3b. Basis sets like aug-cc-pV5Z, aug-cc-pVTZ, etc. 
When increasing the distance, the "through-space" couplings decay roughly as an exponential. The results reported by several authors show a Morse curve appearance (quick decrease, minimum value, very small asymptotic increase). For instance, the ${ }^{129} \mathrm{Xe}-{ }^{131} \mathrm{Xe}$ coupling, as calculated by Salsbury and Harris [8] shows this behavior: ${ }^{1} J_{\mathrm{Xe} \cdots \mathrm{Xe}}=\left[1-\exp \left(-0.41\left(d_{\mathrm{Xe} \cdots \mathrm{Xe}}-9.8\right)\right]^{2}, \mathrm{r}^{2}=0.99\right.$ (Eq. 1), $d_{\mathrm{Xe} \cdots \mathrm{Xe}}$ being the distance in atomic units (see Figure 1).

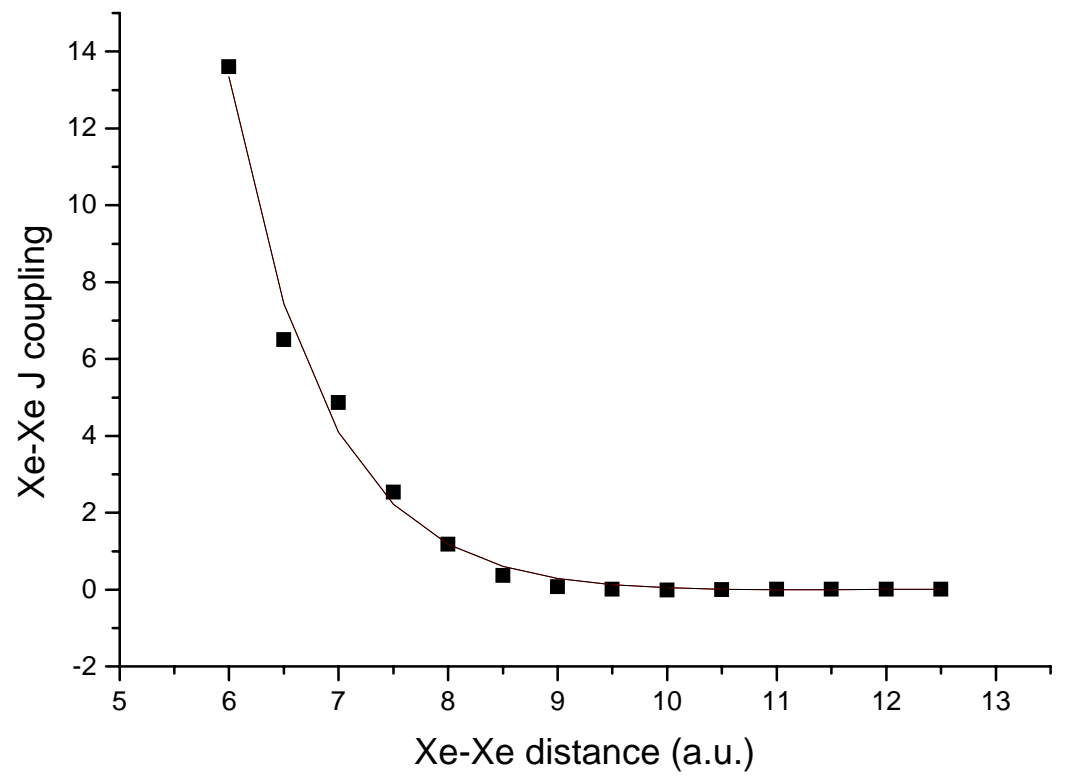

Figure 1. Morse fitting of Salsbury and Harris data (two first points removed)

\section{Hydrogen bonded molecules: couplings through a hydrogen bond}

The hydrogen-bond-induced changes of the intramolecular spin-spin coupling constants will not be discussed systematically (for instance, ${ }^{1} J_{\mathrm{NH}}$ before and after the $\mathrm{NH}$ group was involved in an $\mathrm{HB}$ ). Any hydrogen bond (HB) of the A-H $\cdots$ B type can adopt three limit situations (we will use IMHB for intramolecular hydrogen bonds): classical, shared and proton transfer. In cases were the proton is shared between A and B the distinction between ${ }^{1} J_{\mathrm{AH}}$ and ${ }^{1 \mathrm{~h}} J_{\mathrm{B} \cdots \mathrm{H}}$ disappears; finally, when the proton is completely transferred, the situation again becomes "classical", with ${ }^{1} J_{\mathrm{BH}}$ and ${ }^{1 \mathrm{~h}} J_{\mathrm{A} \cdots \mathrm{H}}$.

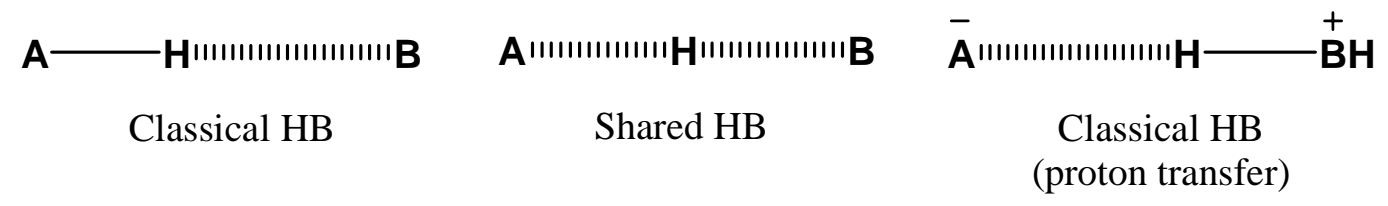

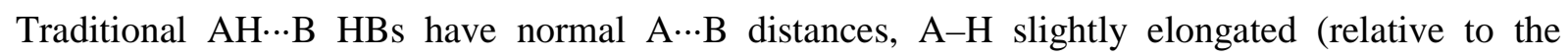
monomer); similarly the ion-pair, $\mathrm{B}^{+}-\mathrm{H} \cdots \mathrm{A}$, have $\mathrm{A} \cdots \mathrm{B}$ distances comparable to the preceding case, $\mathrm{B}^{+}-\mathrm{H}$ slightly elongated (relative to the isolated $\mathrm{B}^{+}-\mathrm{H}$ cation). The proton-shared structure is characterized by a short $\mathrm{A} \cdots \mathrm{B}$ distance and an elongation of the $\mathrm{A} \cdots \mathrm{H}$ and $\mathrm{B} \cdots \mathrm{H}$ distances. 
The contribution of the Bartlett, Perera and Del Bene's group to this topic is so significant that we have decided to divide this section in three parts: a) Other groups [9-24]; b) Bartlett-Perera-Del Bene [25-36]; c) Data analysis [37-41].

a) Other groups. Three publications by Pecul, Sadlej and Leszczynski are noteworthy for the quality of the calculations. In the first one, Pecul and Sadlej [9] described their calculation on water dimer. In the first part they use the conventional case of water monomer (Table 1) to compare different approaches to the calculation of spin-spin coupling constants (they were dominated by the Fermi contact and paramagnetic spin-orbital terms).

Table 1. The nuclear spin-spin coupling constants $(\mathrm{Hz})$ in the water monomer

\begin{tabular}{llll}
\hline & & ${ }^{1} J_{\mathrm{OH}}$ & ${ }^{2} J_{\mathrm{HH}}$ \\
\hline Experimental & & & - \\
& cyclohexane & -78.7 & -7.3 \\
nitromethane & -80.6 & \\
& & & -12.6 \\
& MCSCF (RAS4/HIII) & -77.2 & -9.3 \\
& MCSCF (CAS/HIIIa) & -75.2 & -10.8 \\
\hline
\end{tabular}

${ }^{\mathrm{a}}$ From the literature (different authors) [9].

These results show that MCSCF (included in the DALTON program) when used with a basis set of very high quality are comparable to EOM-CCSD calculations. For the water dimer 1, at the RAS level, they found ${ }^{2 \mathrm{~h}} J_{\mathrm{O} 1-\mathrm{O} 2}=1.6,{ }^{\mathrm{h}} J_{\mathrm{O} 1-\mathrm{H} 5}=4.4,{ }^{3 \mathrm{~h}} J_{\mathrm{O} 1-\mathrm{H} 6}=0.5,{ }^{3 \mathrm{~h}} J_{\mathrm{O} 2-\mathrm{H} 3}=0.2,{ }^{2 \mathrm{~h}} J_{\mathrm{H} 3-\mathrm{H} 5}=0.3$ and ${ }^{4 \mathrm{~h}} J_{\mathrm{H} 3-\mathrm{H} 6}=-0.08$ Hz.

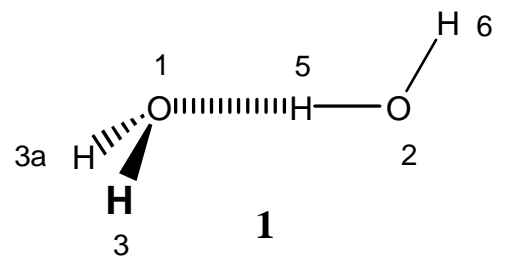

Pecul, Leszczynski and Sadlej published two papers on scalar coupling constants in hydrogen bonded systems. In the first one [10], they studied $\mathrm{X}-\mathrm{H} \cdots \mathrm{O}$ complexes $\left[\mathrm{CH}_{2} \mathrm{O}-\mathrm{H}_{2} \mathrm{O} 2, \mathrm{C}_{2} \mathrm{H}_{2}-\mathrm{H}_{2} \mathrm{O} 3\right.$, $\mathrm{CH}_{3} \mathrm{OH}-\mathrm{H}_{2} \mathrm{O} 4$ and $(\mathrm{HCOOH})_{2}$ 5]. The calculations were carried out at the MCSCF level and the main conclusions are: ${ }^{1 \mathrm{~h}} \mathrm{~J}_{\mathrm{OH}}$ correlates with the strength of the $\mathrm{HB}$ (expressed in terms of the interaction energy); the intermolecular ${ }^{1 \mathrm{~h}} J_{\mathrm{OH}}$ couplings are determined primarily by the FC term (these couplings are similar to those through covalent bonds, what distinguishes them is their magnitude and, 
more surprisingly, their sign); the ${ }^{2 \mathrm{~h}} J_{\mathrm{XY}}$ couplings through the X-H... $\mathrm{Y}$ HB are also dominated by the FC term. In the formic acid dimer $\mathbf{5}$, the ${ }^{2 \mathrm{~h}} J_{\mathrm{OO}}$ coupling attains $7.1 \mathrm{~Hz}$.
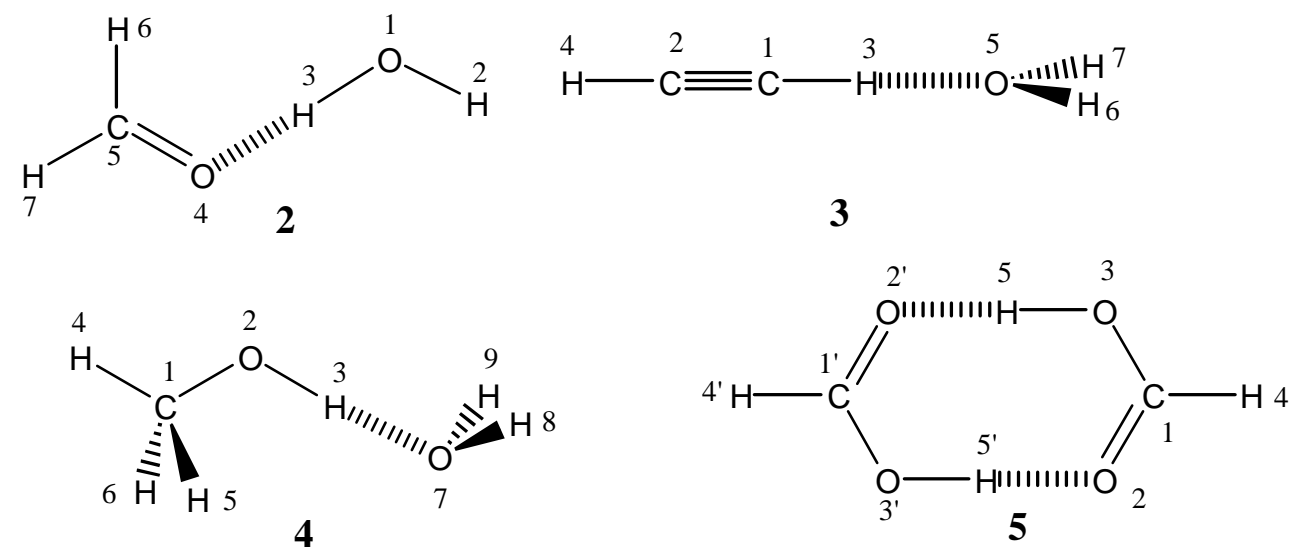

The second paper [11] deals with the important case of $\mathrm{N}-\mathrm{H} \cdots \mathrm{O}=\mathrm{C}$ (this last atom is designed $\mathrm{C}^{\prime}$ in most publications following the common use in peptides) and $\mathrm{N}-\mathrm{H} \cdots \mathrm{N}=\mathrm{C}$ systems. Thus, formamide dimer (Fa-Fa) 6 and formamide-formamidine dimer (Fa-Fi) 7 have been studied at the MCSCF level. Complex 7 should present a large ${ }^{2 \mathrm{~h}} J_{\mathrm{NN}}$ coupling of $8.3 \mathrm{~Hz}$. Another interesting conclusion is that ${ }^{2 \mathrm{~h}} J_{\mathrm{CH}}$ couplings are positive for $\mathrm{N}-\mathrm{H} \cdots \mathrm{N}=\mathrm{C}$ bonds and negative for $\mathrm{N}-\mathrm{H} \cdots \mathrm{O}=\mathrm{C}$ bonds. The authors have examined the variation of the couplings with the ON distance, for instance, there is a fast exponential decay of ${ }^{2 \mathrm{~h}} J_{\mathrm{NN}}$.

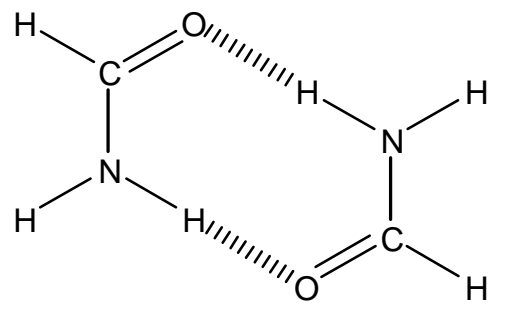

6

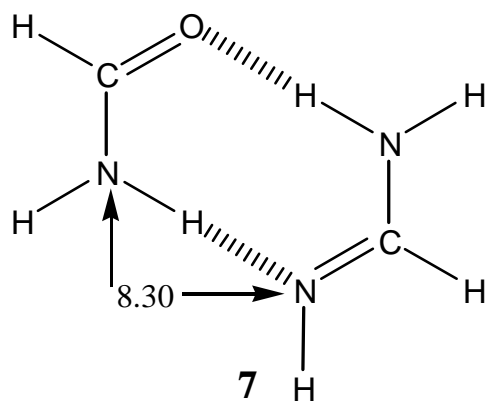

$7 \mathrm{H}$

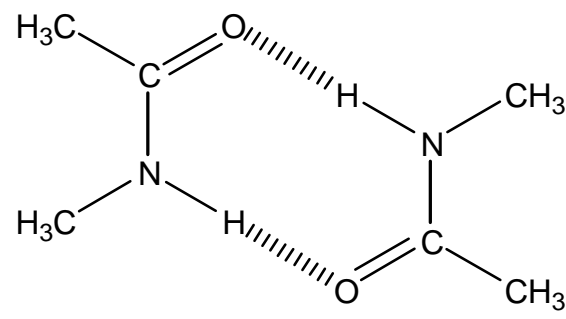

8

Scheurer and Brüschweiler [12] have studied the $N$-methylacetamide dimer $\mathbf{8}$ as a model of the trans-hydrogen ${ }^{3 \mathrm{~h}} \mathrm{~J}_{\mathrm{NC}^{\prime}}$ coupling involved in polypeptide $\mathrm{N}-\mathrm{H} \cdots \mathrm{O}=\mathrm{C}^{\prime}$ hydrogen bonds (trans here does not mean a trans disposition but that the coupling occurs through the HB). Using the DFT-based methodology of Malkin, Malkina and Salahub (SOS-DFTP), they explored the double dependence of ${ }^{3 \mathrm{~h}} J_{\mathrm{NC}}$ with the NO distance and the out-of-plane tilt angle and they showed that there exists a linear correlation between ${ }^{3 \mathrm{~h}} J_{\mathrm{NC}}$ and the isotropic $\mathrm{H}^{\mathrm{N}}$ chemical shift. They computed also the ${ }^{2 \mathrm{~h}} J_{\mathrm{NN}}$ couplings in guanine/cytosine $(5.36 \mathrm{~Hz})$, uracil/adenine $(7.65 \mathrm{~Hz})$ and thymine/adenine pairs $(6.45 \mathrm{~Hz})$.

A second paper by Czernek and Brüschweiler [13] is related to the experimental observation of ${ }^{2 \mathrm{~h}} J\left({ }^{31} \mathrm{P}-{ }^{1} \mathrm{H}\right)$ and ${ }^{3 \mathrm{~h}} J\left({ }^{31} \mathrm{P}_{-}{ }^{15} \mathrm{~N}\right)$ in protein-nucleotide complexes (see Appendix, Table 7). Using the same 
methodological approach, they calculated two complex fragments $\mathbf{9}$ and $\mathbf{1 0}$ with different $\mathrm{N}-\mathrm{H} \cdots \mathrm{O}=\mathrm{P}$ geometries.

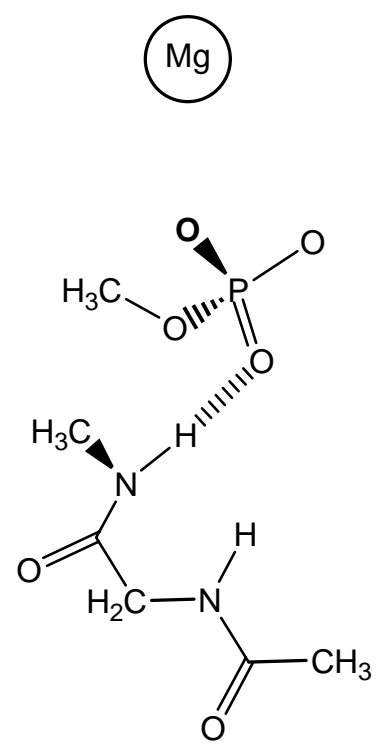

9

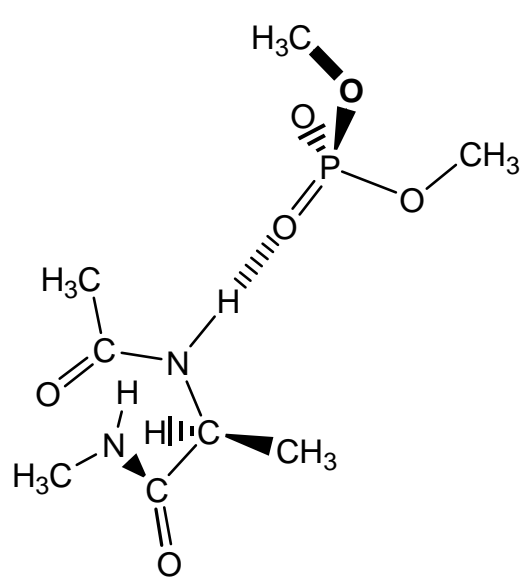

10

Fragment $\mathbf{9}$ is a model of Gly15 together with $\mathrm{Mg}\left[\mathrm{PO}_{4}\left(\mathrm{CH}_{3}\right)\right]$ and fragment $\mathbf{1 0}$ is a model of Ala18 together with $\left[\mathrm{PO}_{4}\left(\mathrm{CH}_{3}\right)_{2}\right]^{-}$. They devised a two-dimensional surface of the form:

$$
{ }^{\mathrm{nh}} J_{\mathrm{PX}}\left(r_{\mathrm{NO}}, \alpha_{\mathrm{POH}}\right)=a_{0} \mathrm{e}^{-\mathrm{a} \cdot \mathrm{r}} \mathrm{NO}\left\{\cos \left(\alpha_{\mathrm{POH}}-\alpha_{\text {offset }}\right)\right\}^{a 2}
$$

Each value of ${ }^{\mathrm{nh}} J_{\mathrm{PX}}$ (for a pair of $\mathrm{N} \cdots \mathrm{O}$ distance and $\mathrm{P}-\mathrm{O} \cdots \mathrm{H}$ angle) depends on a series of parameters that have been calculated. For instance, $a_{0}=-9628.6 \mathrm{~Hz}, a_{1}=2.7232 \AA^{-1}, a_{2}=2.4761$, $\alpha_{\text {offset }}=3.1853 \mathrm{rad}$ for ${ }^{3 \mathrm{~h}} J_{\mathrm{PN}}$. They proposed to use equation (2) in a similar way to the Karplus equation.

It will be interesting to know whether the type of equation known as the Karplus equation is followed in supramolecular complexes. For instance, if the dependence of ${ }^{3} J_{\mathrm{FF}}$ in compound $\mathbf{1 1}$ has a counterpart in ${ }^{4 h} J_{\mathrm{FF}}$ in complex 12.
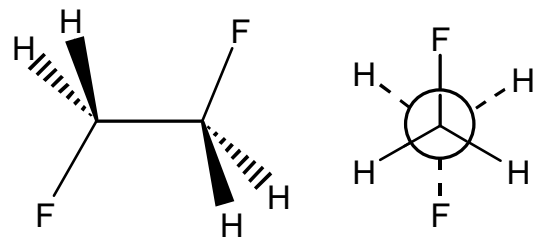

11

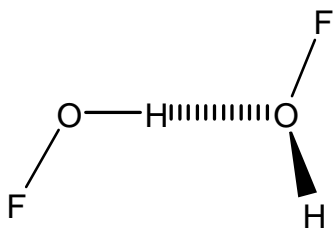

12

Barfield's contribution is important having published four papers between 1999 and 2002 [14-18]. In his first paper, published with Grzesiek, two DNA triplets $13(\mathrm{~T} \cdot \mathrm{A}-\mathrm{T})$ and $\mathbf{1 4}\left(\mathrm{C}^{+} \cdot \mathrm{G}-\mathrm{C}\right)$ were studied 
theoretically (DFT-FTP//UB3PW91/6-311G**) to be compared with their experimental results (Table 7 of the Appendix) [14,15]. In these systems, two trans-hydrogen bond ${ }^{2 \mathrm{~h}} J_{\mathrm{NN}}$ and ${ }^{1 \mathrm{~h}} J_{\mathrm{HN}}$ scalar couplings were calculated. Interesting correlations were found between the chemical shift of the proton of the $\mathrm{HB}$ and ${ }^{1 \mathrm{~h}} J_{\mathrm{HN}}$ (positive), ${ }^{2 \mathrm{~h}} J_{\mathrm{NN}}$ (positive) and ${ }^{1} J_{\mathrm{NH}}$ (negative), both between calculated values (Eqs. 3 and 4) and between experimental values (Eq. 5).

$$
\begin{aligned}
& { }^{1} J_{\mathrm{HN}}=-91.9+1.01 \delta^{1} \mathrm{H}, \mathrm{r}^{2}=0.984 \\
& { }^{2 \mathrm{~h}} J_{\mathrm{NN}}=-9.4+1.17 \delta^{1} \mathrm{H}, \mathrm{r}^{2}=0.9999 \\
& { }^{2 \mathrm{~h}} J_{\mathrm{NN}}=-9.6+1.27 \delta^{1} \mathrm{H}, \mathrm{r}^{2}=0.861
\end{aligned}
$$

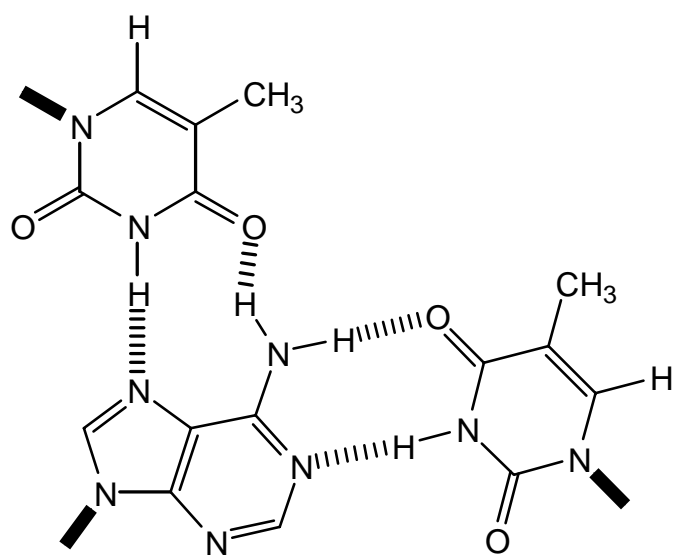

13

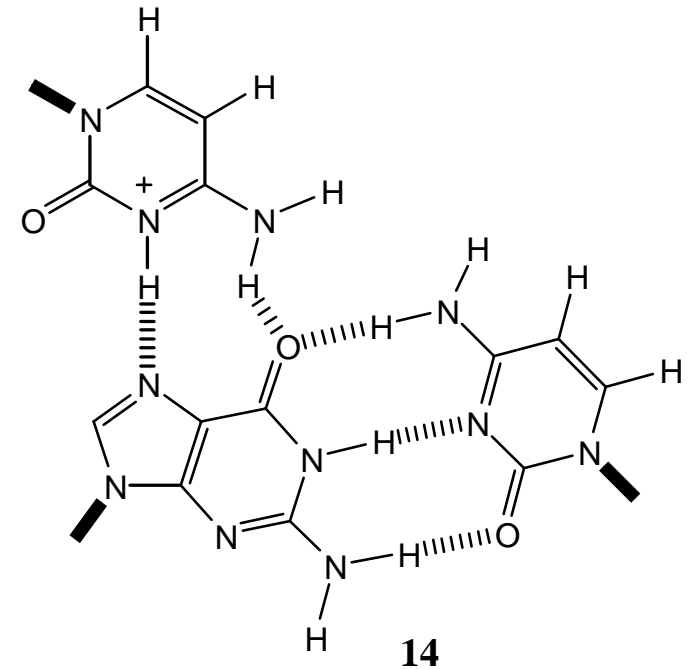

Barfield, O'Leary et al. measured (see Table 7, Appendix) ${ }^{2 \mathrm{~h}} J_{\mathrm{HH}}$ couplings in 1,3 and 1,4-diols of favorable conformation and computed (DFT/FTP) these couplings for different geometries of the fragment $\mathrm{O}-\mathrm{H} \cdots \mathrm{O}-\mathrm{H}$ with acceptable results $[16,17]$. In his last publication, Barfield addressed the problem of proteins, and specifically, the notorious ${ }^{3 \mathrm{~h}} J_{\mathrm{NC}^{\prime}}$ coupling [18]. He used as a model, formamide dimer, but instead of a cyclic dimer, like $\mathbf{6}$, he used a more realistic open-dimer $\mathbf{1 5}$.

He found that ${ }^{3 \mathrm{~h}} \mathrm{~J}_{\mathrm{NC}}$ depends on $r_{\mathrm{OH}}, \theta_{1}, \theta_{2}$ and the torsion angle $\rho$ about the $\mathrm{C}=\mathrm{O}$ bond $\left(\mathrm{H} \cdots \mathrm{O}=\mathrm{C}^{\prime}-\right.$ $\mathrm{N})$. Several equations were devised in this very important publication. Those relating ${ }^{3 \mathrm{~h}} J_{\mathrm{NC}}$ with $\cos ^{2} \rho$ bear a clear similarity with the Karplus relationship.

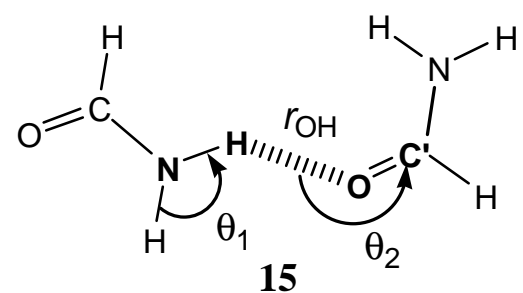


The authors of one of the most widely used methods for calculating coupling constants, Malkin and Malkina, collaborated with Limbach in the study of the experimental findings of these last authors (reported in Table 7). Thanks to experiments at very low temperatures (between 110 and $150 \mathrm{~K}$ ) using freons as solvents, Golubev, Limbach and their coworkers measured ${ }^{1} \mathrm{H}^{-19} \mathrm{~F}$ coupling constants in fluoride ion/hydrogen fluoride complexes (see Scheme 1) [19].

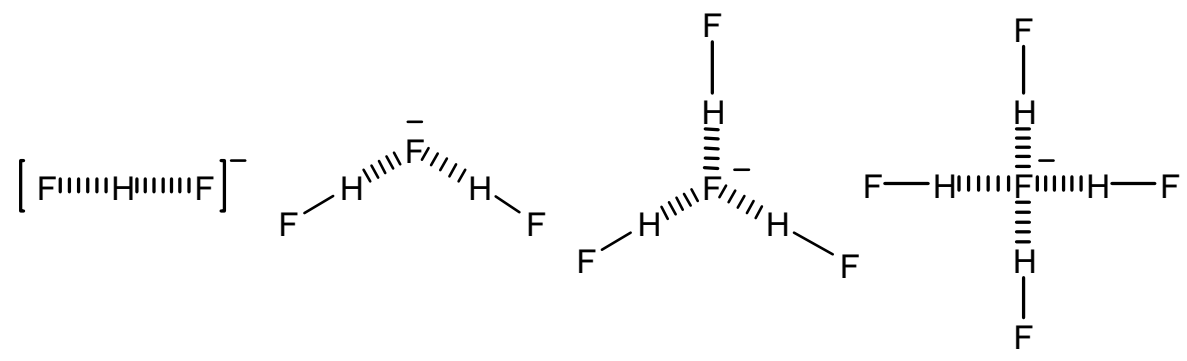

Scheme 1. Species formed by mixing HF and tetrabutylammonium fluoride

They measured or estimated all the possible coupling constants that were also calculated at the MCLR-CAS level [19]. This collection of data is still remarkable for the wealth of information it contains being completely apart from peptides, nucleic acids or their combination.

The second publication is of a more theoretical nature [20]. The authors used the famous SteinerLimbach diagrams, where geometrical (such as $\mathrm{q}_{2}$ ) and NMR properties (such as $\delta^{1} \mathrm{H}$ of the $\mathrm{H}$ in the $\mathrm{HB},{ }^{\mathrm{n}} J$ and ${ }^{\mathrm{nh}} J$ ) were represented against $\mathrm{q}_{1}$ :

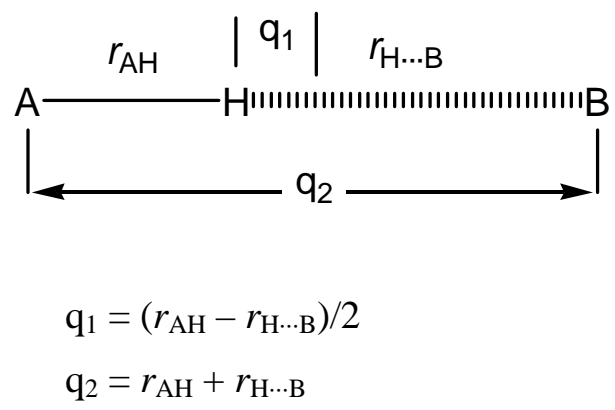

The cases of $\left[\mathrm{F}(\mathrm{HF})_{n}\right]^{-}, n=1-4$, discussed above, of $[\mathrm{C} \equiv \mathrm{N} \cdots \mathrm{H} \cdots \mathrm{N} \equiv \mathrm{C}]^{-}$, formamidine dimer 16 were calculated. For instance, we report below the calculated value (in $\mathrm{Hz}$ ) of ${ }^{2 \mathrm{~h}} J_{\mathrm{NN}}$ of $\mathbf{1 6}$.

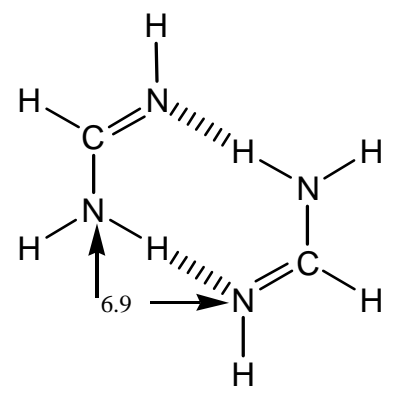


Although not reporting coupling constants, a third paper by Limbach is worth quoting because it describes the influence of an electric field on the geometry and properties of A-H $\cdots B$ complexes [21].

Bagno has examined the case of formamide dimer 15 in relation with the case of ubiquitin (see Table 7) [22]. He has built up the coupling surface of ${ }^{3 \mathrm{~h}} \mathrm{~J}_{\mathrm{NC}^{\prime}}$ in function of the $\mathrm{N} \cdots \mathrm{O}$ distance and the dihedral angle. His conclusions, based on FTP/DFT calculations are similar to those of Barfield [18], which were obtained two years later.

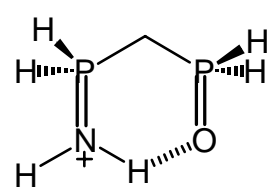

$17 \mathbf{a}\left(C_{S}\right)$

$\phi_{1}=\phi_{2}=0^{\circ}$

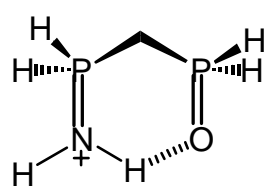

$17 \mathbf{b}\left(C_{1}\right)$

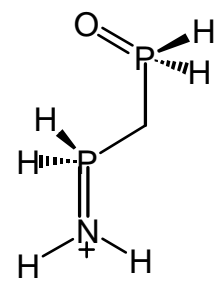

$18\left(C_{s}\right)$

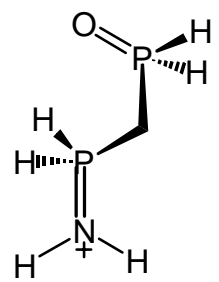

$19\left(C_{1}\right)$

$\phi_{1}=172.3^{\circ}, \phi_{2}=-3.6^{\circ}$

Finally, we have calculated the coupling constants of structures 17-19 in an attempt to determine whether the coupling of $1.5 \mathrm{~Hz}$ between ${ }^{15} \mathrm{~N}$ and ${ }^{31} \mathrm{P}$ (not directly bonded) is transmitted through the skeleton $\left({ }^{4} J_{\mathrm{NP}}\right)$ or through the HB $\left({ }^{3 \mathrm{~h}} J_{\mathrm{NP}}\right)$ [23]. Only the Fermi contact term was calculated using the FTP/B3LYP/aug-cc-pVTZ approach. The conclusion is that the main transmission pathway is through the covalent bonds.

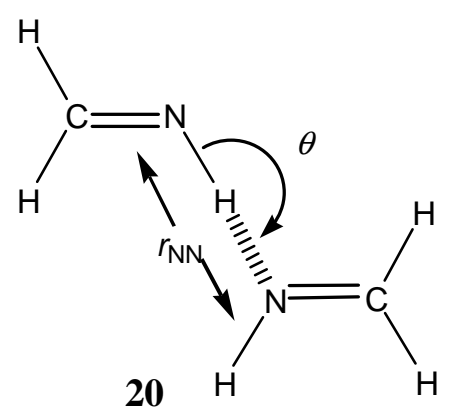

Bryce and Wasylishen have modeled the ${ }^{2 \mathrm{~h}} J_{\mathrm{NN}}$ in nucleic acid base pairs using methylene-imine dimer 20 in function of hydrogen bond geometry $\left(r_{\mathrm{NN}}\right.$ and $\theta$ ) [24]. The variation of ${ }^{2 \mathrm{~h}} J_{\mathrm{NN}}$ as a function of $r_{\mathrm{NN}}$ is fit to an exponential decay $\left[r_{\mathrm{NN}}=3.36-0.37 \ln \left({ }^{2 \mathrm{~h}} J_{\mathrm{NN}}\right)\right]$. The influence of $\theta$ is less pronounced.

b) Bartlett, Perera, Del Bene's contribution [25-36].

Remember that all papers by this group are based on high-level EOM-CCSD calculations. Perera and Bartlett [25] initiated their systematic exploration of scalar couplings through hydrogen-bonds inspired by Limbach-Malkina's paper on $[\mathrm{FHF}]^{-}$and $\left[\mathrm{F}(\mathrm{HF})_{n}\right]^{-}(n=1-4)$ [20]. These authors criticize the use of DFT methods when dealing with fluorine atoms "The MCLR results reported for [FHF] ${ }^{-}$by Limbach et al. are unrealistic". The estimated value for ${ }^{2 \mathrm{~h}} J_{\mathrm{FF}}$ is $>200 \mathrm{~Hz}$, the MCLR calculated value 
is $-133 \mathrm{~Hz}$ and the EOM-CCSD value is $+225 \mathrm{~Hz}$. We will see in the following discussion that ${ }^{19} \mathrm{~F}$ NMR properties are amongst the most difficult to calculate.

In the second publication of the same authors with Del Bene [26], they examined the case of the "low-barrier" hydrogen bonds, a topic of general interest for its biological implications, trying to find out whether predicted NMR coupling constants across hydrogen bonds can be used as fingerprints for specifying hydrogen bond types. They calculated a certain number of ${ }^{17} \mathrm{O}-{ }^{17} \mathrm{O},{ }^{15} \mathrm{~N}-{ }^{15} \mathrm{~N}$ and ${ }^{15} \mathrm{~N}-{ }^{17} \mathrm{O}$ systems (Table 2). Amongst their main conclusions are that for these nuclei, the FC term dominates, that the relationship between ${ }^{2 \mathrm{~h}} J_{\mathrm{OO}}(\mathrm{Hz})$ and $d_{\mathrm{OO}}(\AA)$ shows an exponential decay, and that ${ }^{2 \mathrm{~h}} J_{\mathrm{NN}}$ for $d_{\mathrm{NN}}=2.9 \AA$ is $7.2 \mathrm{~Hz}$ close to the experimental findings (see Table 7).

Table 2. NMR total and FC coupling constants $(\mathrm{Hz})$ for A-H-B systems

\begin{tabular}{|c|c|c|c|c|c|}
\hline Complex & $\mathrm{AB}$ & HB type ${ }^{a}$ & $d_{\mathrm{AB}}(\AA)$ & Fermi-contact $(\mathrm{Hz})$ & $J_{\text {total }}(\mathrm{Hz})$ \\
\hline $\mathrm{O}_{2} \mathrm{H}_{5}^{+}$ & $\mathrm{OO}$ & PS & 2.38 & 39.92 & 39.54 \\
\hline $\mathrm{O}_{2} \mathrm{H}_{3}^{-}$ & $\mathrm{OO}$ & PS & 2.44 & 16.28 & 17.96 \\
\hline $\mathrm{O}_{2} \mathrm{H}_{4}$ & $\mathrm{OO}$ & $\mathrm{T}$ & 2.91 & 1.47 & 1.29 \\
\hline${ }^{+} \mathrm{H}_{2} \mathrm{OH}: \mathrm{NCH}$ & $\mathrm{ON}$ & PS & 2.47 & 34.07 & 34.12 \\
\hline $\mathrm{HOH}: \mathrm{NC}^{-}$ & $\mathrm{ON}$ & $\mathrm{T}$ & 2.82 & 6.62 & 6.55 \\
\hline $\mathrm{CNH}: \mathrm{OH}_{2}$ & NO & $\mathrm{T}$ & 2.84 & 8.57 & 8.51 \\
\hline $\mathrm{HOH}: \mathrm{NCH}$ & $\mathrm{ON}$ & $\mathrm{T}$ & 3.13 & 1.14 & 1.16 \\
\hline${ }^{+} \mathrm{HCNH}: \mathrm{NCH}$ & $\mathrm{NN}$ & PS & 2.52 & 32.46 & 32.52 \\
\hline $\mathrm{CNH}: \mathrm{NC}^{-}$ & NN & PS & 2.58 & 21.47 & 21.52 \\
\hline CNH:NCH & $\mathrm{NN}$ & $\mathrm{T}$ & 3.00 & 5.60 & 5.62 \\
\hline
\end{tabular}

Then, Del Bene and Jordan examined the case of the complex between hydrogen chloride and ammonia that Del Bene had already studied in what concerns its geometry, energy and vibrational aspects [27]. To the $\mathrm{Cl}-\mathrm{H} \cdots \mathrm{NH}_{3}$ complex they applied an external electric field along the $\mathrm{HB}$ to modify the character of the HB, an approach already used by Limbach and ourselves [21]. When the field increases, the system moves from traditional, to shared, to ion-pair. We report their most significant results in Table 3. They criticized the use by Limbach and ourselves of the q coordinates concluding that they are only useful for symmetric systems (which is not correct), that the FC term dominates and showing that ${ }^{2 \mathrm{~h}} J_{15 \mathrm{~N}-35 \mathrm{Cl}}$ is negative. 
Table 3. Equilibrium $\mathrm{Cl} \cdots \mathrm{N}$ distances, proton chemical shifts and ${ }^{2 \mathrm{~h}} J_{15 \mathrm{~N}-35 \mathrm{Cl}}$ coupling constants as functions of external field strength

\begin{tabular}{lllc}
\hline Field (a.u.) & $d_{\mathrm{Cl} \cdots \mathrm{N}}(\AA)$ & $\delta(\mathrm{ppm})$ & ${ }^{2 \mathrm{~h}} J_{15 \mathrm{~N}-35 \mathrm{Cl}}(\mathrm{Hz})$ \\
\hline 0.0000 & 3.080 & 10.0 & -5.7 \\
0.0010 & 3.056 & 10.8 & -6.1 \\
0.0025 & 3.019 & 12.0 & -6.9 \\
0.0040 & 2.975 & 13.6 & -8.0 \\
0.0055 & 2.832 & 20.9 & -11.8 \\
0.0100 & 2.896 & 19.1 & -9.1 \\
0.0150 & 3.004 & 16.4 & -6.7 \\
\hline
\end{tabular}

Contrary to most authors, they prefer graphical representations to statistical models. Their graphs clearly showed that their seven data belong to two families, the first set corresponds to $0.0000-0.0040$ a.u. fields and the second one to 0.0055-0.0150 a.u. fields. These sets can be adjusted to linear correlations, although they probably correspond to the two branches of an exponential [21] (eqs. 8-13).

First set (traditional Cl-H...N HB):

$$
\begin{aligned}
& d_{\mathrm{N} \cdots \mathrm{Cl}}=(3.082 \pm 0.002)-(26.2 \pm 0.9) \text { field, } \mathrm{n}=4, \mathrm{r}^{2}=0.998 \\
& \delta^{\mathrm{l}} \mathrm{H}=(8.93 \pm 0.11)+(893 \pm 47) \text { field, } \mathrm{n}=4, \mathrm{r}^{2}=0.994 \\
& { }^{2 \mathrm{~h}} J_{\mathrm{Cl} \cdots \mathrm{N}}=-(5.60 \pm 0.11)-(576 \pm 49) \text { field, } \mathrm{n}=4, \mathrm{r}^{2}=0.986
\end{aligned}
$$

Second set (ion-pair $\mathrm{Cl}^{-} \cdots \mathrm{H}-\mathrm{N}^{+} \mathrm{HB}$ ):

$$
\begin{aligned}
& d_{\mathrm{N} \cdots \mathrm{Cl}}=(2.73 \pm 0.02)+(18 \pm 2) \text { field, } \mathrm{n}=3, \mathrm{r}^{2}=0.987 \\
& \delta^{\mathrm{l}} \mathrm{H}=(23.6 \pm 0.4)-(475 \pm 40) \text { field, } \mathrm{n}=3, \mathrm{r}^{2}=0.993 \\
& { }^{2 \mathrm{~h}} J_{\mathrm{Cl} \cdots \mathrm{N}}=-(14.6 \pm 0.3)+(536 \pm 35) \text { field, } \mathrm{n}=3, \mathrm{r}^{2}=0.996
\end{aligned}
$$

The proton shared situation is very unstable [21] and should be found in the 0.0040-0.0055 au region.

The next contribution by Del Bene and Bartlett was devoted to the ${ }^{2 \mathrm{~h}} J_{\mathrm{NN}}$ coupling present in some ${ }^{15} \mathrm{~N}-\mathrm{H} \cdots{ }^{15} \mathrm{~N}$ fragment [28] (see Table 7). Here again, the FC term dominates, other terms being negligible. Their results are reported in Table 4 (note that is ${ }^{2 \mathrm{~h}} J_{\mathrm{NN}}$ positive).

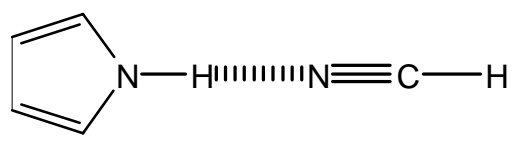

21

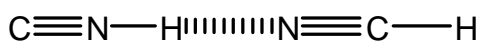

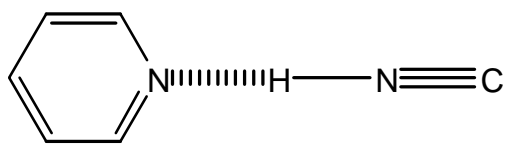

23 
Table 4. Equilibrium $\mathrm{N} \cdots \mathrm{N}$ distances, symmetry and ${ }^{2 \mathrm{~h}} J_{15 \mathrm{~N}-15 \mathrm{~N}}$ coupling constants

\begin{tabular}{lccc}
\hline \multicolumn{1}{c}{ Complex } & symmetry & $d_{\mathrm{N} \cdots \mathrm{N}}(\AA)$ & ${ }^{2 \mathrm{~h}} J_{15 \mathrm{~N}-15 \mathrm{~N}}(\mathrm{~Hz})$ \\
\hline pyrrole:NCH (21) & $C_{2 v}$ & 3.16 & 3.0 \\
$\mathrm{CNH}: \mathrm{NCH}(\mathbf{2 2})$ & $C_{\infty}$ & 3.00 & 5.5 \\
$\mathrm{CNH}: \mathrm{NH}_{3}$ & $C_{3 v}$ & 2.85 & 8.7 \\
$\mathrm{CNH}: \mathrm{NCLi}$ & $C_{\infty v}$ & 2.83 & 9.6 \\
$\mathrm{CNH}:$ pyridine $(\mathbf{2 3})$ & $C_{2 v}$ & 2.79 & 10.7 \\
\hline
\end{tabular}

Reference [29] reports the calculations carried out on the problem of a long range coupling constant present in iminophosphorane-substituted proton-sponges 24 (see Table 7). Using as a model structure 25, the results reported in Table 5 were found (only the FC term was computed).

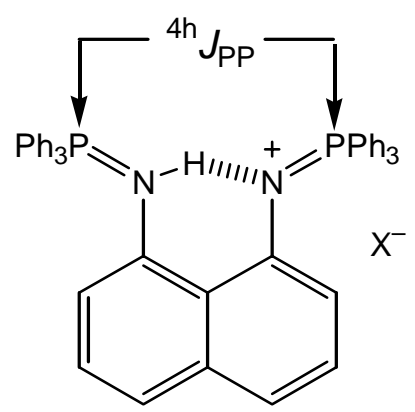

24

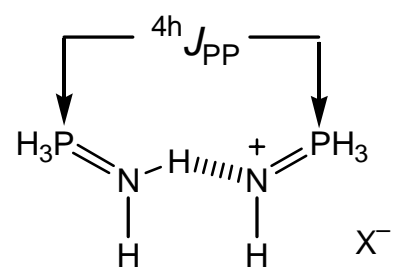

25

Table 5. N $\cdots \mathrm{N}$ and P..P distances and computed ${ }^{4 h} J_{31 \mathrm{P}-31 \mathrm{P}}$ coupling constants in model 25

\begin{tabular}{lcc}
\hline $\mathrm{N} \cdots \mathrm{N}$ distance $(\AA)$ & $\mathrm{P} \cdots \mathrm{P}$ distance $(\AA)$ & ${ }^{4 \mathrm{~h}} J_{31 \mathrm{P}-31 \mathrm{P}}(\mathrm{Hz})$ \\
\hline 2.53 & 4.79 & 14.3 \\
2.83 & 5.09 & 8.1 \\
3.03 & 5.29 & 5.9 \\
3.33 & 5.59 & 3.9 \\
3.53 & 5.79 & 3.0 \\
\hline
\end{tabular}

These data can be analyzed statistically leading to eqs. (14) and (15):

$$
\begin{gathered}
d_{\mathrm{P} \cdots \mathrm{P}}=(2.27 \pm 0.02)+(0.997 \pm 0.003) d_{\mathrm{N} \cdots \mathrm{N}}, \mathrm{n}=5, \mathrm{r}^{2}=1.000 \\
\ln { }^{4 h} J_{31 \mathrm{P}-31 \mathrm{P}}=(6.96 \pm 0.10)-(4.66 \pm 0.09) \ln d_{\mathrm{N} \cdots \mathrm{N}}, \mathrm{n}=5, \mathrm{r}^{2}=0.999
\end{gathered}
$$

Del Bene, Parera and Bartlett used in another contribution the reduced coupling constants $K$ to correct some erroneous statements about the relative importance of scalar couplings [30]; for the N- 
$\mathrm{H}^{+}-\mathrm{N}$ and $\mathrm{O}-\mathrm{H}^{+}-\mathrm{O}$ complexes ${ }^{2 \mathrm{~h}} K_{\mathrm{X} \cdots \mathrm{X}}>{ }^{1} K_{\mathrm{X}-\mathrm{H}}>{ }^{1 \mathrm{~h}} K_{\mathrm{X} \cdots \mathrm{X}}$. Jordan, Del Bene et al. devoted another paper to the $\mathrm{N}-\mathrm{H} \cdots \mathrm{N}$ system [31]. They used the pyrrole:hydrogen cyanide (21) and the hydrogen isocyanide:hydrogen cyanide (22) systems and, as perturbation, an electric field or chemical substitution (fluorine and $\mathrm{Be}^{2+}$ on the pyrrole, $\mathrm{Li}, \mathrm{Na}, \mathrm{S}^{-}$and $\mathrm{O}^{-}$instead of $\mathrm{H}$ in $\mathrm{NCH}$ ). Some of their results are reported in Table 6.

Table 6. Chemical shifts of the hydrogen-bonded proton and ${ }^{2 \mathrm{~h}} J_{15 \mathrm{~N}-15 \mathrm{~N}}$ coupling constants as a function of field strength

\begin{tabular}{lcc}
\hline Field (a.u) & $\delta^{\mathrm{l}} \mathrm{H}(\mathrm{ppm})$ & ${ }^{2 \mathrm{~h}} J_{15 \mathrm{~N}-15 \mathrm{~N}}(\mathrm{~Hz})$ \\
\hline 0.0000 & 1.9 & 6.4 \\
0.0040 & 2.4 & 7.3 \\
0.0100 & 3.2 & 8.8 \\
0.0150 & 4.1 & 10.3 \\
0.0200 & 5.2 & 12.3 \\
0.0225 & 6.0 & 13.7 \\
0.0250 & 7.1 & 15.5 \\
\hline
\end{tabular}

In all cases, proton-shared and ion-pair $\mathrm{N}_{\mathrm{a}}-\mathrm{H}-\mathrm{N}_{\mathrm{b}}$ HBs are unlikely to be formed in neutral complexes. These authors introduced an important representation to understand the nature and properties of hydrogen-bonded systems, plotting $\mathrm{N}_{\mathrm{a}}-\mathrm{H}(\AA)$ against $\mathrm{N}_{\mathrm{b}}-\mathrm{H}(\AA)$ and representing the square of the ground-state vibrational wave function superimposed on the potential energy surface.

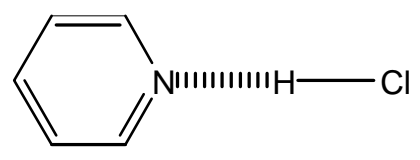

26

The next problem they tackled concerns the hydrogen chloride:pyridine complex (26) [32]. Pyridine is a very good HBA because the positive charge can be delocalized over the ring. In this example, increasing the field, they succeeded to attain the proton-shared and afterwards the ion-pair structures. They carried out the calculations using an isotropic external electric field (analogous to the Onsager's model), optimizing the structure for each field (under some restrictions) and then calculating the coupling constants with the field turned off (turning on the external field during the calculations increases the absolute value of ${ }^{2 \mathrm{~h}} J_{35 \mathrm{Cl} \cdots 15 \mathrm{~N}}$ ). Their calculations are in agreement with Limbach's results on temperature effects o HBs: decreasing the temperature corresponds to an increase of the field and the traditional system evolves to proton-shared and then to ion pair.

Del Bene, Jordan, Parera and Bartlett [33] returned to the problem of ${ }^{2 \mathrm{~h}} J_{\mathrm{FF}}$ in [FHF] $^{-}$and [FDF] ${ }^{-}$ that was their first publication on scalar couplings across HBs [25]. They examined the possible effects of zero-point vibrational effects and of vibrational averaging, to conclude that both have essentially no 
effect on ${ }^{2 \mathrm{~h}} J_{\mathrm{FF}}$. They confirmed that, although the FC term dominates, the PSO term is also important.

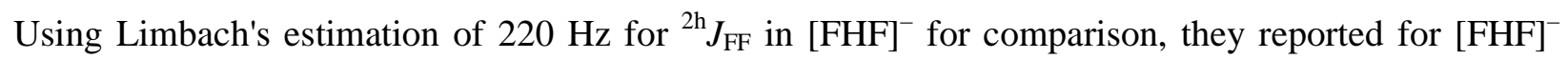
$212.7 \mathrm{~Hz}$ and for $[\mathrm{FDF}]^{-} 223.1 \mathrm{~Hz}$. This is an important result that allows a new entrance to isotope effects.

Two papers [34,35] can be consulted to get an overview of the preceding series of papers. One dealing with ${ }^{15} \mathrm{~N},{ }^{15} \mathrm{~N}$ spin-spin coupling constants across $\mathrm{N}-\mathrm{H}-\mathrm{N}$ and $\mathrm{N}-\mathrm{H}^{+}-\mathrm{N}$ hydrogen bonds and entitled "Can coupling constants provide reliable estimates of N-N distances in biomolecules?" (with a positive answer both for the distance and the angular variations) and the other with "what a difference a decade makes: progress in ab initio studies of the hydrogen bond".

The last paper until now reports calculations of ${ }^{3 \mathrm{~h}} J_{15 \mathrm{~N}-31 \mathrm{P}}$ spin-spin coupling constants across NH...O-P hydrogen bonded complexes [36]. This work is similar in subject but different in methodology to that of Czernek and Brüschweiler [12]. Instead of complex structures 9 and 10, equation-of-motion coupled cluster singles and doubles (EOM-CCSD) calculations were performed in model cationic and anionic complexes including $\mathrm{NH}_{4}{ }^{+}: \mathrm{OPH}, \mathrm{NH}_{4}{ }^{+}: \mathrm{OPH}_{3}, \mathrm{NH}_{3}:{ }^{-} \mathrm{O}_{2} \mathrm{PH}_{2}, \mathrm{NFH}_{2}:{ }^{-} \mathrm{O}_{2} \mathrm{PH}_{2}$, and $\mathrm{NF}_{2} \mathrm{H}^{-} \mathrm{O}_{2} \mathrm{PH}_{2}$. Three-bond coupling constants can be appreciable when the phosphorous is $\mathrm{P}(\mathrm{V})$, but are negligible with $\mathrm{P}(\mathrm{III}) .{ }^{3 \mathrm{~h}} J_{\mathrm{N}-\mathrm{P}}$ values in complexes with cyclic or open structures are less than $1 \mathrm{~Hz}$, a consequence of the nonlinear arrangement of N, H, O, and P atoms. For complexes with these structures, ${ }^{3 \mathrm{~h}} J_{\mathrm{N}-\mathrm{P}}$ may not be experimentally measurable. In contrast, complexes in which the $\mathrm{N}, \mathrm{H}, \mathrm{O}$, and $\mathrm{P}$ atoms are collinear or nearly collinear have larger values of ${ }^{3 \mathrm{~h}} J_{\mathrm{N}-\mathrm{P}}$, even though the N-P distances are longer than $\mathrm{N}-\mathrm{P}$ distances in cyclic and open structures. In linear complexes, ${ }^{3 \mathrm{~h}} \mathrm{~J}_{\mathrm{N}-\mathrm{P}}$ is dominated by the Fermicontact term, which is distance dependent. Therefore, N-P (and hydrogen-bonding N-O) distances in these complexes can be determined from experimentally measured ${ }^{15} \mathrm{~N}-{ }^{31} \mathrm{P}$ coupling constants.

\section{c) Data analysis.}

Peralta, Contreras et al. analyzed using NBOs (Natural Bonding Orbitals) the C-H...O interaction in $\mathrm{NCH} \cdots \mathrm{OH}_{2}$ and $\mathrm{NCH} \cdots \mathrm{O}=\mathrm{CH}_{2} 27$ and their effect on nuclear magnetic shielding constants [37]. In a subsequent paper, they expanded the same methodology to the dissection of fluorine-fluorine couplings (see below, 31). They proposed a partition of the Fermi contact term as a sum of contributions of core orbitals, non-bonding electron pairs and bonding orbitals. As expected the coupling constant through the space are governed by the non-bonding electron pair term in all the cases studied [38].
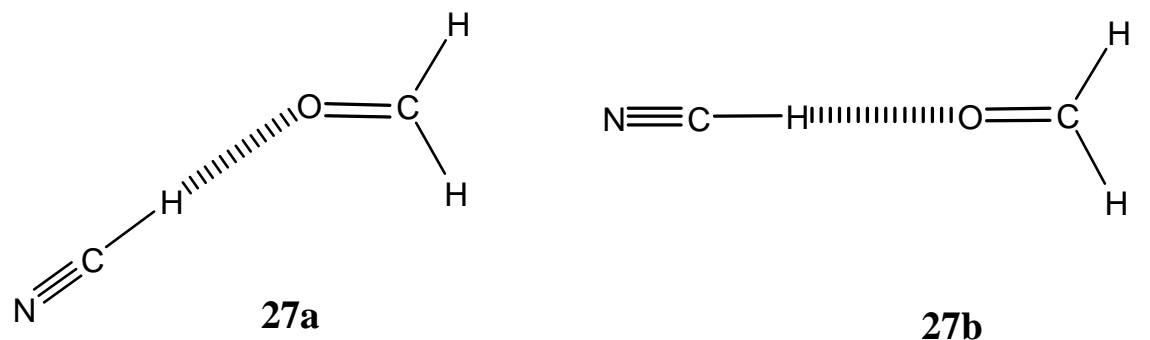
Weinhold, the creator of NBO analysis, applied his method first to an example of covalent bonds $\left({ }^{3} J_{\mathrm{HH}}\right.$ couplings in ethane) [39] and then to ${ }^{1 \mathrm{~h}} J_{\mathrm{NH}}$ and ${ }^{2 \mathrm{~h}} J_{\mathrm{NN}}$ in DNA A-T base pair [3]. The contributions of the orbitals involved in the HB to the coupling constants are able to explain the differences observed between the ${ }^{2 \mathrm{~h}} J_{\mathrm{NN}}$ and ${ }^{1 \mathrm{~h}} J_{\mathrm{NH}}$ [3]. Arnold, Oldfield et al. used DFT theory to calculate and analyze through-space ${ }^{19} \mathrm{~F}_{-}{ }^{19} \mathrm{~F}$ coupling constants [40] and found an exponential relationship between the coupling constant value and the internuclear distance. The same authors compared the ${ }^{\mathrm{nh}} J_{\mathrm{NC}}$ in proteins with the electron density properties obtained using Bader's Theory of Atoms in Molecules (AIM) [41]. They found an exponential relationship between the mutual penetration of the electronic clouds and the coupling constant values.

\section{Hydrogen bonded molecules: couplings through a dihydrogen bond}

This fascinating topic has been covered recently [42], we have replaced the letter h of hydrogen bonds by the letter $\mathrm{d}$ of dihydrogen bonds. EOM-CCSD calculations were performed to determine onebond $\left({ }^{1 \mathrm{~d}} J_{\mathrm{H}-\mathrm{H}}\right)$ and three-bond $\left({ }^{3 \mathrm{~d}} J_{\mathrm{X}-\mathrm{M}}\right)$ spin-spin coupling constants across $\mathrm{X}-\mathrm{H} \cdots \mathrm{H}-\mathrm{M}$ dihydrogen bonds for complexes with ${ }^{13} \mathrm{C}-{ }^{1} \mathrm{H},{ }^{15} \mathrm{~N}-{ }^{1} \mathrm{H}$, and ${ }^{17} \mathrm{O}-{ }^{1} \mathrm{H}$ proton-donor groups and proton-acceptor metal hydrides ${ }^{7} \mathrm{Li}-{ }^{1} \mathrm{H}$ and ${ }^{23} \mathrm{Na}-{ }^{1} \mathrm{H}$. Unlike two-bond spin-spin coupling constants across N-H-N, N-H-O, O$\mathrm{H}-\mathrm{O}$, and $\mathrm{Cl}-\mathrm{H}-\mathrm{N}$ hydrogen bonds, which are determined solely by the Fermi-contact term (see above), ${ }^{1 \mathrm{~d}} J_{\mathrm{H}-\mathrm{H}}$ receives non-negligible contributions from the PSO and DSO terms. However, these terms tend to cancel, so that the curve for the distance-dependence of ${ }^{1 \mathrm{~d}} J_{\mathrm{H}-\mathrm{H}}$ is determined by the distancedependence of the Fermi-contact term. The value of ${ }^{1 \mathrm{~d}} J_{\mathrm{H}-\mathrm{H}}$ is dependent on the nature of the protondonor and proton acceptor, and the relative orientation of the bonded pair. Hence, it would be difficult to extract structural information from experimentally measured coupling constants without a model tailored specifically for the experimental complex. ${ }^{3 \mathrm{~d}} J_{\mathrm{C}-\mathrm{Li}}$ values for the equilibrium structures of seven linear complexes stabilized by $\mathrm{C}-\mathrm{H} \cdots \mathrm{H}-\mathrm{Li}$ bonds are dependent on $\mathrm{C}-\mathrm{Li}$ distances, and are also sensitive to structural changes which remove any one of these four atoms from the dihydrogen bond. ${ }^{3 \mathrm{~d}} J_{\mathrm{O}-\mathrm{M}}$ for the complexes $\mathrm{HOH}: \mathrm{HLi}$ and $\mathrm{HOH}: \mathrm{HNa}$ exhibit unusual behavior as a function of the O-M distance, increasing with increasing distance through a change of sign, reaching a maximum, and then subsequently decreasing.

\section{Van der Waals complexes}

The number of publications devoted to the study of scalar couplings in van der Waals complexes is much more reduced than those concerning HBs. The reason is fairly simple: there are no experimental results! Therefore, the only existing papers reported explorations of hypothetical situations, although their conclusions are important: i) the transmission of the scalar nuclear spin-spin coupling is a 
property not restricted to the HBs; ii) the existence of the nuclear spin-spin coupling transmitted through an interaction is not an evidence of the covalent character of this interaction.

Salsbury and Harris [8] examined the case of the xenon dimer. Exploiting the fact that xenon has two isotopes with spins $\neq 0\left({ }^{129} \mathrm{Xe}\right.$, spin $I=1 / 2$, and ${ }^{131} \mathrm{Xe}$, spin $\left.I=3 / 2\right)$, they have calculated the FC term for the $\mathrm{Xe}_{2}$ and for the $\mathrm{Xe}-{ }^{1} \mathrm{H}$ complexes. In the regions of interest $J(\mathrm{Xe}-\mathrm{H})$ is microHz and $J\left({ }^{129} \mathrm{Xe}-{ }^{131} \mathrm{Xe}\right)$ is milliHz.

More recently, a similar study was carried out on $\mathrm{He}_{2}\left({ }^{3} \mathrm{He}\right.$, spin 1/2). Obviously, this coupling is not accessible experimentally. At the energy minimum $(5.6$ a.u. $=2.96 \AA)$, the coupling should amount to $1.3 \mathrm{~Hz}$ [43]. All the terms were calculated at the EOM-CCSD level, but only FC is important. The same author with Sadlej and Leszczynski [44] has calculated that the $\mathrm{HF} \cdot \mathrm{CH}_{4}$ van der Waals dimer should have a $J_{\mathrm{HF}} \approx 4 \mathrm{~Hz}$. In this same paper they reported calculations of the [FHF] ${ }^{-}$anion (Scheme 1) and the $\mathrm{F}-\mathrm{H} \cdots \mathrm{F}-\mathrm{H}$ dimer. Bryce and Wasylishen extended these calculations to $\mathrm{HF} \cdots \mathrm{CH}_{3} \mathrm{~F}$ (in two conformations) [45]; they found that the isotropic coupling constants are dominated by the Fermicontact mechanism.

At lower level (DFT, only FC, PSO and DSO terms) but much more complex structures, Bagno, Saielli and Scorrano [46] carried out calculations on three van der Waals complexes: methane-methane dimer (not reported), methane-benzene 28 and benzene-benzene (T-shaped) 29.

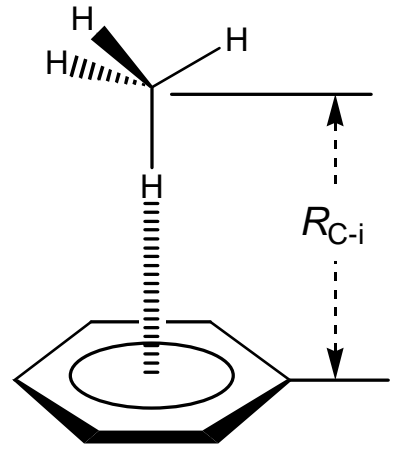

28

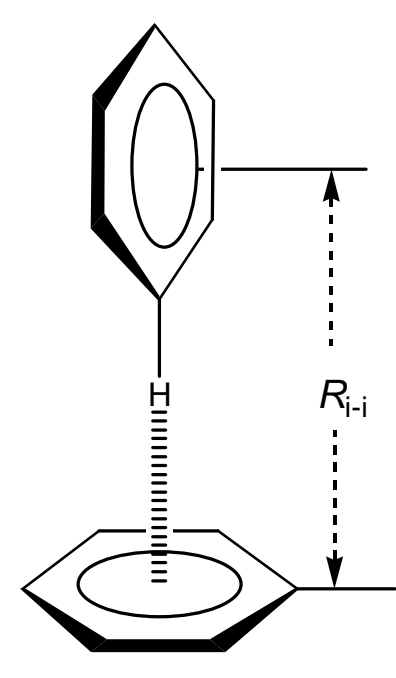

29

The ${ }^{1} \mathrm{H}-{ }^{1} \mathrm{H}$ couplings are very small, for all purposes null, but the ${ }^{1} \mathrm{H}-{ }^{13} \mathrm{C}$ should be in the $0.2-0.3$ $\mathrm{Hz}$ range (for equilibrium geometries, $R_{\mathrm{C}-\mathrm{i}}=3.685 \AA$ and $R_{\mathrm{i}-\mathrm{i}}=4.90 \AA$ ) and therefore experimentally measurable. However, these model systems are not suitable for an experimental verification due to their too-large exchange rate compared to their small couplings. A better candidate would be the ${ }^{15} \mathrm{~N}$ ${ }^{19} \mathrm{~F}$ coupling in the complex $\mathrm{CH}_{3}-\mathrm{CN} \cdots \mathrm{C}_{6} \mathrm{~F}_{6} 30$ [47]. 


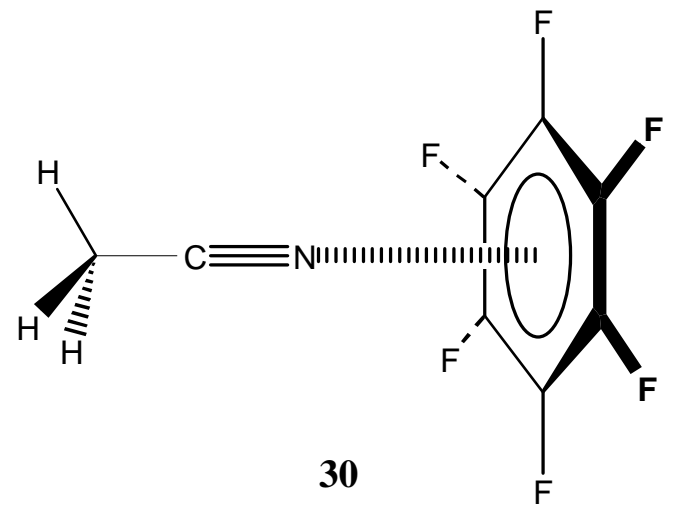

Bagno, Saielli and Scorrano [48] have examined a large set of van der Waals complexes $\left(\mathrm{CH}_{4} / \mathrm{CH}_{4}\right.$, $\mathrm{CH}_{4} / \mathrm{C}_{2} \mathrm{H}_{4}, \mathrm{C}_{2} \mathrm{H}_{4} / \mathrm{C}_{2} \mathrm{H}_{4}, \mathrm{CH}_{4} / \mathrm{C}_{6} \mathrm{H}_{6} 28, \mathrm{C}_{6} \mathrm{H}_{6} / \mathrm{C}_{6} \mathrm{H}_{6}$ 29) as well as some more realistic and complex systems in search of type 2 interactions (calixarene $/ \mathrm{CH}_{3} \mathrm{CN}$, the Tröger's balance of Wilcox, etc.).

This is probably the best place to describe the attempts of two groups to analyze the ${ }^{19} \mathrm{~F} /{ }^{19} \mathrm{~F}$ nuclear spin-spin coupling through-space. Both used, as a model, two hydrogen fluoride molecules, Peralta, Contreras et al. [38] in disposition 31 and Mallory et al. [50] in disposition 32.

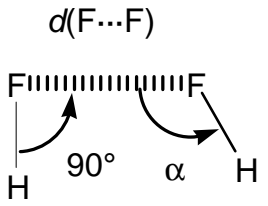

31

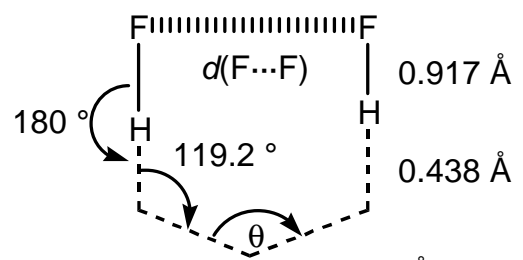

$1.410 \AA$

32

The second authors did not carry out calculations on ${ }^{19} \mathrm{~F}^{19} \mathrm{~F}$ couplings, and concluded only that there is an exponential relationship between $J_{\mathrm{FF}}$ and $d(\mathrm{~F} \cdots \mathrm{F})$ [50]. Peralta, Contreras and Snyder have carried out a natural bond order (NBO) dissection of $J_{\mathrm{FF}}$ [38].

\section{Conclusions}

We are, at the end of 2002, in an interesting and unstable situation: the calculation of scalar couplings shows the same impetus and problems as some ten years ago did the calculation of nuclear shieldings, being still highly demanding on computational effort. The authors face a difficult election: either to considerably simplify the problem or to lower the level of the method to the point to obtain dubious results. Even with a considerable simplification, there are problems accessible only to people having access to big supercomputational centers.

It is expected than in the next ten years, development in software and hardware will allow some fascinating problems to be tackled. For instance, other interactions deserved to be explored like inverse 
HBs [51,52], three-centered (bifurcated) HBs [53], charge-transfer bonds [54], etc. One of the main objectives that should be approached in the next years is the calculation of coupling constants including heavy atoms (therefore, including relativistic corrections) because the structure of many fundamental problems in chemistry (catalysis) and biochemistry involve these atoms.

We hope that this review will encourage other physicists, chemists, biochemists, molecular biologists and NMR spectroscopists to endeavor the calculation of spin-spin scalar coupling constants.

\section{Appendix}

We feel useful to summarize in Table 7 the experimentally measured nuclear spin-spin coupling constants through a hydrogen bond, because they are the test used for many theoretical works [55-99]. Two cases have to be distinguished: intermolecular and intramolecular HBs (these last we will name as IMHBs). The first class is without ambiguity but not so the second one. We consider coupling constants through $\mathrm{HBs}$ between different aminoacids of the same protein, due to folding, as intermolecular coupling constants. Couplings observed in IMHBs can be transmitted through the HB or through the covalent skeleton. The transmission through the skeleton could represent up to a $100 \%$ of the observed coupling. There is no experimental possibility to separate both mechanisms and even not a theoretical partition method available. These couplings through IMHBs have been ascribed to ${ }^{n h} J_{S}$ with the qualitative argument that, in similar compounds, the skeleton is unable to transmit the spin information. Some of them are illustrated in Scheme 2.

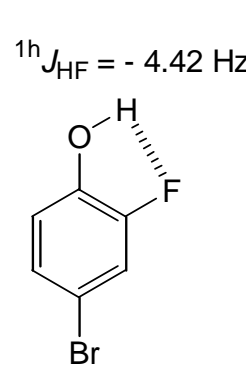

33 [51]

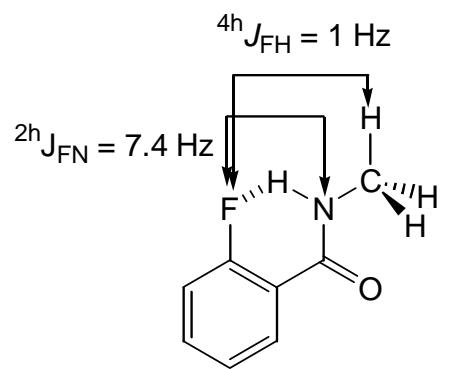

$34[58]$

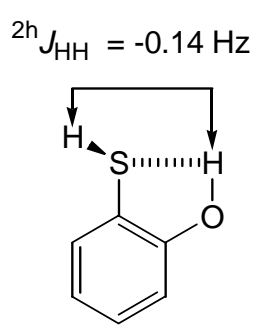

35 [59]

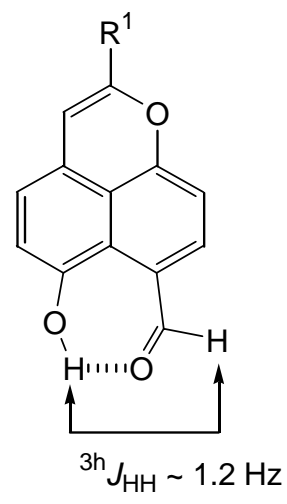

38 [70]

Scheme 2. Some examples of scalar couplings through intramolecular HBs (IMHB) 
Amongst the intermolecular HBs, the most common situations are summarized in Scheme 3. They are found both in nucleic acids and in proteins (in this last case, the atoms of the second aminoacid residue are noted with a dash).
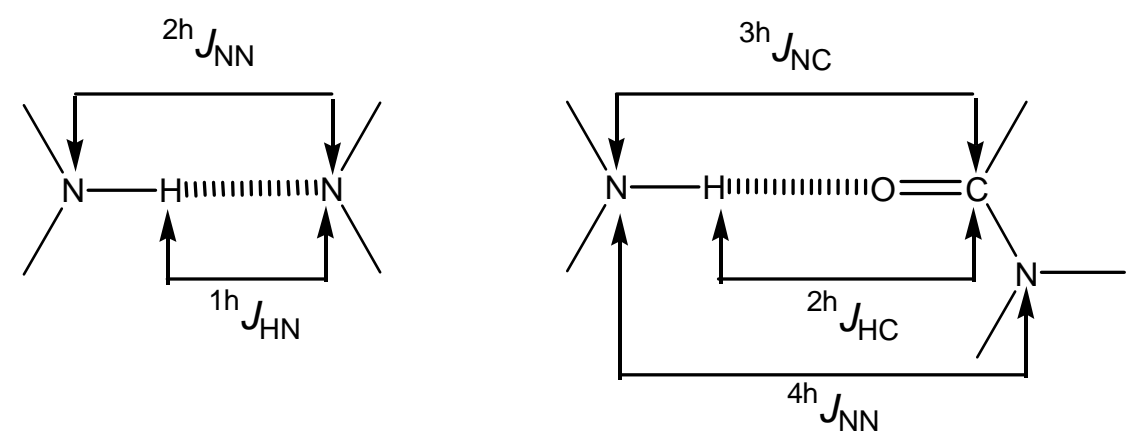

Scheme 3. The most frequent intermolecular couplings

Especially noteworthy is reference [91]; there, for the first time, a coupling constant through a hydrogen bond was measured in the solid state $\left[{ }^{2}{ }^{2 h} J\left({ }^{15} \mathrm{~N}-\mathrm{H} \cdots{ }^{15} \mathrm{~N}\right)\right]$ : this opens extraordinary expectations for the study of ${ }^{\mathrm{nh}} \mathrm{J}$ in intermolecular simple systems where there is not a single example. 
Table 7. Experimental coupling constants through hydrogen bonds

\begin{tabular}{|c|c|c|c|}
\hline Compound & Couplings measured & $\mathrm{HB}$ & Ref. \\
\hline \multicolumn{4}{|c|}{${ }^{1 \mathrm{~h}} J_{\mathrm{S}}$} \\
\hline $\mathrm{F} \cdots \mathrm{H}$ & ${ }^{1 \mathrm{~h}} J_{\mathrm{F} \cdots \mathrm{H}}$ & IMHB & {$[55]$} \\
\hline$[\mathrm{F} \cdots \mathrm{H} \cdots \mathrm{F}]^{-}$ & ${ }^{1 \mathrm{~h}} J_{\mathrm{F} \cdots \mathrm{H}}$ & inter & [19] \\
\hline$[\mathrm{F} \cdots \mathrm{H} \cdots \mathrm{N}($ collidine $)]$ & ${ }^{1 \mathrm{~h}} J_{\mathrm{F} \cdots \mathrm{H}}$ & inter & {$[56,57]$} \\
\hline$[\mathrm{F} \cdots \mathrm{H} \cdots \mathrm{N}($ collidine $)]$ & ${ }^{1 \mathrm{~h}} J_{\mathrm{N} \cdots \mathrm{H}}$ & inter & {$[56,57]$} \\
\hline$\left[\mathrm{RCO}_{2}{ }^{-} \cdots \mathrm{H} \cdots \mathrm{N}(\right.$ pyridine $\left.)\right]$ & ${ }^{1 \mathrm{~h}} J_{\mathrm{N} \cdots \mathrm{H}}$ & inter & {$[58]$} \\
\hline [Pyridine $\cdots \mathrm{H}+\cdots$ pyridine] & ${ }^{1 \mathrm{~h}} J_{\mathrm{N} \cdots \mathrm{H}}$ & inter & [59] \\
\hline DNA, RNA & ${ }^{1 h} J_{N \cdots H}$ & inter & [14-16,60-67] \\
\hline Nucleic acids & ${ }^{1 \mathrm{~h}} J_{\mathrm{N} \cdots \mathrm{H}}$ & inter & {$[68-72]$} \\
\hline Fulvenes & ${ }^{1 \mathrm{~h}} J_{\mathrm{N} \cdots \mathrm{H}}$ & IMHB & {$[73-75]$} \\
\hline \multicolumn{4}{|c|}{${ }^{2 \mathrm{~h}} J \mathrm{~s}$} \\
\hline$[\mathrm{F} \cdots \mathrm{H} \cdots \mathrm{F}]-$ & ${ }^{2 \mathrm{~h}} J_{\mathrm{F}-\mathrm{H} \cdots \mathrm{F}}$ & inter & {$[19]$} \\
\hline$[\mathrm{F} \cdots \mathrm{H} \cdots \mathrm{N}($ collidine $)]$ & ${ }^{2 \mathrm{~h}} J_{\mathrm{F}-\mathrm{H} \cdots \mathrm{N}}$ & inter & {$[56-57]$} \\
\hline $\mathrm{N}-\mathrm{H} \cdots \mathrm{F}$ & ${ }^{2 h} J_{N-H \cdots F}$ & IMHB & [76] \\
\hline $\mathrm{H}-\mathrm{S} \cdots \mathrm{H}$ & ${ }^{2 \mathrm{~h}} J_{\mathrm{H}-\mathrm{S} \cdots \mathrm{H}}$ & IMHB & [77] \\
\hline $\mathrm{H}-\mathrm{O} \cdots \mathrm{H}$ & ${ }^{2 \mathrm{~h}} J_{\mathrm{H}-\mathrm{O} \cdots \mathrm{H}}$ & IMHB & {$[16,78]$} \\
\hline $\mathrm{H} \cdots \mathrm{O} \cdots \mathrm{H}$ & ${ }^{2 \mathrm{~h}} J_{\mathrm{H} \cdots \mathrm{O} \cdots \mathrm{H}}$ & IMHB & [79] \\
\hline Proteins & ${ }^{2 \mathrm{~h}} J_{\mathrm{C}=\mathrm{O} \cdots \mathrm{H}}(\mathrm{N}-\mathrm{H} \cdots \mathrm{O}=\mathrm{C})$ & inter & [80-90] \\
\hline DNA, RNA & ${ }^{2 h} J_{\mathrm{N}-\mathrm{H} \cdots \mathrm{N}}$ & inter & {$[14-16,60-67]$} \\
\hline Nucleic acids & ${ }^{2 h} J_{N-H \cdots N}$ & inter & {$[68-72]$} \\
\hline Apomyoglobin & ${ }^{2 \mathrm{~h}} J_{\mathrm{N}-\mathrm{H} \cdots \mathrm{N}}($ imidazole $\cdots \mathrm{H}$-imidazolium) & inter & {$[91]$} \\
\hline Proton sponges & ${ }^{2 \mathrm{~h}} J_{\mathrm{N}-\mathrm{H} \cdots \mathrm{N}}$ & IMHB & {$[92]$} \\
\hline Fulvenes & ${ }^{2 \mathrm{~h}} J_{\mathrm{N}-\mathrm{H} \cdots \mathrm{N}}$ & IMHB & {$[73-75,93]$} \\
\hline Protein/DNA & ${ }^{2 \mathrm{~h}} J_{\mathrm{P}=\mathrm{O} \cdots \mathrm{H}}(\mathrm{P}=\mathrm{O} \cdots \mathrm{H}-\mathrm{N})$ & inter & [94] \\
\hline Flavoprotein & ${ }^{2 \mathrm{~h}} J_{\mathrm{P}-\mathrm{O} \cdots \mathrm{H}}(\mathrm{P}=\mathrm{O} \cdots \mathrm{H}-\mathrm{N}, \mathrm{P}=\mathrm{O} \cdots \mathrm{H}-\mathrm{O})$ & inter & [95] \\
\hline Metalloprotein & ${ }^{2 \mathrm{~h}} J_{\mathrm{Cd} \cdots \mathrm{H}}(\mathrm{N}-\mathrm{H} \cdots \mathrm{S}-\mathrm{Cd})$ & inter & {$[96,97]$} \\
\hline Metalloprotein & ${ }^{2 \mathrm{~h}} J_{\mathrm{Hg} \cdots \mathrm{H}}(\mathrm{N}-\mathrm{H} \cdots \mathrm{S}-\mathrm{Hg})$ & inter & {$[97]$} \\
\hline \multicolumn{4}{|c|}{${ }^{3 \mathrm{~h}} J \mathrm{~s}$} \\
\hline $\mathrm{H}-\mathrm{C}=\mathrm{O} \cdots \mathrm{H}-\mathrm{O}$ & ${ }^{3 \mathrm{~h}} J_{\mathrm{H}-\mathrm{C}=\mathrm{O} \cdots \mathrm{H}}$ & IMHB & {$[98]$} \\
\hline Galactal & ${ }^{3 h} J_{H-O \cdots H}(O-H \cdots O-H)$ & IMHB & [99] \\
\hline $\mathrm{H}-\mathrm{C}-\mathrm{O} \cdots \mathrm{H}$ & ${ }^{3 \mathrm{~h}} J_{\mathrm{H}-\mathrm{C}-\mathrm{O} \cdots \mathrm{H}}$ & IMHB & {$[78]$} \\
\hline Proteins & ${ }^{3 \mathrm{~h}} J_{\mathrm{N}-\mathrm{H} \cdots \mathrm{O}=\mathrm{C}^{\prime}}$ & inter & {$[80-90]$} \\
\hline Nucleic acids & ${ }^{3 \mathrm{~h}} J_{\mathrm{N}-\mathrm{H} \cdots \mathrm{O}=\mathrm{C}}$ & inter & {$[68-72]$} \\
\hline Protein/DNA & ${ }^{3 \mathrm{~h}} J_{\mathrm{N}-\mathrm{H} \cdots \mathrm{O}=\mathrm{P}}$ & inter & {$[68-72]$} \\
\hline \multicolumn{4}{|c|}{${ }^{4 \mathrm{~h}} J \mathrm{~S}$} \\
\hline $\mathrm{H}-\mathrm{C}-\mathrm{N}-\mathrm{H} \cdots \mathrm{F}$ & ${ }^{4 h} J_{H-C-N-H \cdots F}$ & IMHB & [76] \\
\hline Proton sponges & ${ }^{4 h} J_{\mathrm{P}=\mathrm{N}}+{ }_{-\mathrm{H}} \cdots \mathrm{N}=\mathrm{P}$ & IMHB & {$[100,101]$} \\
\hline Nucleotides & ${ }^{4 \mathrm{~h}} J_{\mathrm{H}-\mathrm{C}-\mathrm{N} \cdots \mathrm{H}-\mathrm{N}}$ & inter $^{\mathrm{a}}$ & {$[102,103]$} \\
\hline
\end{tabular}

${ }^{\text {a }}$ Observation of the interaction but $J$ was not measured. 


\section{References}

1. Harris, R. K.; Kowalewski, J.; De Menezes, S. C. Parameters and symbols for use in Nuclear Magnetic Resonance. Pure Appl. Chem. 1997, 69, 2489-2495.

2. Raynes, W. T. A proposal concerning the units of the reduced nuclear spin-spin coupling constant. Magn. Reson. Chem. 1992, 30, 686.

3. Wilkens, S. J.; Westler, W. M.; Weinhold, F.; L. Markley, J. L. Trans-hydrogen-bond ${ }^{\mathrm{h} 2} J_{\mathrm{NN}}$ and ${ }^{\mathrm{h} 1} J_{\mathrm{NH}}$ couplings in the DNA A-T base pair: Natural Bond Orbital analysis. J. Am. Chem. Soc. 2002, 124, 1190-1191.

4. Bour, P.; Budesinsky, M. Sum-over-states of the nuclear spin-spin coupling constants. J. Chem. Phys. 1999, 110, 2836-2843.

5. Sychrovsky, V.; Gräfenstein, J.; Cremer, D. Nuclear magnetic resonance spin-spin coupling constants from coupled perturbed density functional theory. J. Chem. Phys. 2000, 113, 35303547.

6. Peralta, J. E.; Barone, V.; Contreras, R. H.; Zaccari, D. G., Snyder, J. P. Through-bond and through-space $J_{\mathrm{FF}}$ spin-spin coupling in peridifluoronaphthalenes: Accurate DFT evaluation of the four contributions. J. Am. Chem. Soc. 2001, 123, 9162-9163.

7. Helgaker, T.; Jaszunski, M.; Ruud, K. Ab initio methods for the calculation of NMR shielding and indirect spin-spin-coupling constants. Chem. Rev. 1999, 99, 293-352.

8. Salsbury, F. R.: Harris, R. A. Estimation of the Fermi contact contribution to the xenon-hydrogen and xenon-xenon spin-spin coupling constants. Mol. Phys. 1998, 94, 307-312.

9. Pecul, M.; Sadlej, J. The nuclear spin-spin coupling constants in the water dimer. Chem. Phys. Lett. 1999, 308, 486-494.

10. Pecul, M.; Leszczynski, J.; Sadlej, J. Comprehensive ab initio studies of nuclear magnetic resonance shielding and coupling constants in $\mathrm{XH} \cdots \mathrm{O}$ hydrogen-bonded complexes of simple organic molecules. J. Chem. Phys. 2000, 112, 7930-7938.

11. Pecul, M.; Leszczynski, J.; Sadlej, J. The shielding constants and scalar couplings in N-H..O:C and N-H $\cdots \mathrm{N}: \mathrm{C}$ hydrogen bonded systems: An ab initio MO study. J. Phys. Chem. A 2000, 104, 8105-8113.

12. Scheurer, C.; Brüschweiler, R. Quantum-chemical characterization of nuclear spin-spin couplings across hydrogen bonds. J. Am. Chem. Soc. 1999, 121, 8661-8662.

13. Czernek, J.; Brüschweiler, R. Geometric dependence of ${ }^{3 \mathrm{~h}} J\left({ }^{31} \mathrm{P}_{-}{ }^{15} \mathrm{~N}\right)$ and ${ }^{2 \mathrm{~h}} J\left({ }^{31} \mathrm{P}-{ }^{1} \mathrm{H}\right)$ scalar couplings in protein-nucleotide complexes. J. Am. Chem. Soc. 2001, 123, 11079-11080.

14. Dingley, A. J.; Masse, J. E.; Peterson, R. D.; Barfield, M.; Feigon, J.; Grzesiek, S. Internucleotide scalar couplings across hydrogen Bonds in Watson-Crick and Hoogsteen base pairs of a DNA triplex. J. Am. Chem. Soc. 1999, 121, 6019-6027.

15. Barfield, M.; Dingley, A. J.; Feigon, J.; Grzesiek, S. A DFT study of the interresidue dependencies of scalar $J$-coupling and magnetic shielding in the hydrogen-bonding regions of a DNA triplex. J. Am. Chem. Soc. 2001, 123, 4014-4022.

16. Fierman, M.; Nelson, A.; Khan, S. I.; Barfield, M.; O'Leary, D. J. Scalar Coupling Across the 
Hydrogen Bond in 1,3- and 1,4-Diols. Org. Lett. 2000, 2, 2077-2080.

17. Barfield, M.; Bergset, J. M.; O'Leary, D. J. Density functional theory studies of transannular ${ }^{1} \mathrm{H}-$ ${ }^{1} \mathrm{H} J$-coupling in half-cage alcohols and rigid 1,3- and 1,4-diols: Conformational dependencies and implications for intramolecular hydrogen bond detection in carbohydrates. Magn. Reson. Chem. 2001, 39, S115-S125.

18. Barfield, M. Structural Dependencies of interresidue scalar coupling ${ }^{\mathrm{h} 3} J_{\mathrm{NC}^{\prime}}$ and donor ${ }^{1} \mathrm{H}$ chemical shifts in the hydrogen bonding regions of proteins. J. Am. Chem. Soc. 2002, 124, 41584168.

19. Shenderovich, I. G.; Smirnov, S. N.; Denisov, G. S.; Gindin, V. A.; Golubev, N. S.; Dunger, A.; Reibke, R.; Kirpekar, S.; Malkina, O. L.; Limbach, H.-H. Nuclear magnetic resonance of hydrogen-bonded clusters between $\mathrm{F}^{-}$and $(\mathrm{HF})_{\mathrm{n}}$. Experiment and theory. Ber. Bunsen-Phys. Ges. 1998, 102, 422-428.

20. Benedict, H.; Shenderovich, I. G.; Malkina, O. L.; Malkin, V. G.; Denisov, G. S.; Golubev, N. S.; Limbach, H.-H. Nuclear scalar spin-spin couplings and geometries of hydrogen bonds. J. Am. Chem. Soc. 2000, 122, 1979-1988.

21. Ramos, M.; Alkorta, I.; Elguero, J.; Golubev, N. S.; Denisov, G. S.; Benedict, H.; Limbach, H.$\mathrm{H}$. Theoretical study of the infulence of electric fields on hydrogen-bonded acid-base complexes. J. Phys. Chem. A 1997, 101, 9791-9800.

22. Bagno, A. Quantum chemical modeling of through-hydrogen bond spin-spin coupling in amides and ubiquitin. Chem.-Eur. J. 2000, 6, 2925-2930.

23. López-Leonardo, C.; Alajarín, M.; Llamas-Lorente, P.; Bautista, D.; Jimeno, M. L.; Alkorta, I.; Elguero, J. The molecular structure and NMR properties of $P$-phosphinoylmethyl aminophosphonium salts. Struct. Chem. submitted.

24. Bryce, D. L.; Wasylishen, R. E. Modeling ${ }^{2 \mathrm{~h}} J_{\text {iso }}(\mathrm{N}, \mathrm{N})$ in nucleic acid base pairs: $A b$ initio characterization of the ${ }^{2 \mathrm{~h}} J(\mathrm{~N}, \mathrm{~N})$ tensor in the methyleneimine dimer a a function of hydrogen bond geometry. J. Biomol. NMR 2001, 19, 371-375.

25. Perera, S. A.; Bartlett, R. J. NMR spin-spin coupling constants for hydrogen bonds of $\left[\mathrm{F}(\mathrm{HF})_{\mathrm{n}}\right]^{-}$, n =1-4, clusters. J. Am. Chem. Soc. 2000, 122, 1231-1232.

26. Del Bene, J. E.; Perera, S. A.; Bartlett, R. J. Predicted NMR coupling constants across hydrogen bonds: A fingerprint for specifying hydrogen bond type? J. Am. Chem. Soc. 2000, 122, 35603561.

27. Del Bene, J. E.; Jordan, M. J. T. Vibrational spectroscopic and NMR properties of hydrogenbonded complexes. Do they tell us the same thing? J. Am. Chem. Soc. 2000, 122, 4794-4797.

28. Del Bene, J. E.; Bartlett, R. J. N-N spin-spin coupling constants $\left[{ }^{2 \mathrm{~h}} J\left({ }^{15} \mathrm{~N}-{ }^{15} \mathrm{~N}\right)\right]$ across N-H $\cdots \mathrm{N}$ hydrogen bonds in neutral complexes. To what extent does the bonding at the nitrogens influence ${ }^{2 \mathrm{~h}} J_{\mathrm{N}-\mathrm{N}}$ ? J. Am. Chem. Soc. 2000, 122, 10480-10481.

29. Del Bene, J.; Perera, S. A.; Bartlett, R. J.; Alkorta, I.; Elguero, J. $\left.{ }^{4 h} \mathrm{~J}^{31} \mathrm{P}-{ }^{31} \mathrm{P}\right)$ coupling constants through $\mathrm{N}-\mathrm{H}^{+}-\mathrm{H}$ hydrogen bonds: A Comparison of computed ab initio and experimental data. $J$. Phys. Chem. A, 2000, 104, 7165-7166. 
30. Del Bene, J. E.; Perera, S. A.; Bartlett, R. J. What parameters determine N-N and O-O coupling constants $\left({ }^{2 \mathrm{~h}} J_{\mathrm{X}-\mathrm{X}}\right)$ across $\mathrm{X}-\mathrm{H}^{+}-\mathrm{X}$ hydrogen bonds? J. Phys. Chem. A 2001, 105, 930-934.

31 Toh, J. S.-S.; Jordan, M. J. T.; Husowitz, B. C.; Del Bene, J. E. Can Proton-Shared or ion-pair $\mathrm{N}-\mathrm{H}-\mathrm{N}$ hydrogen bonds be produced in uncharged complexes? A systematic ab initio study of the structures and selected NMR and IR properties of complexes with $\mathrm{N}-\mathrm{H}-\mathrm{N}$ hydrogen bonds. J. Phys. Chem. A 2001, 105, 10906-10914.

32. Chapman, K.; Crittenden, D.; Bevitt, J.; Jordan, M. J. T.; Del Bene, J. E. Relating environmental effects and structures, IR, and NMR properties of hydrogen-bonded complexes: ClH:Pyridine. $J$. Phys. Chem. A 2001, 105, 5442-5449.

33. Del Bene, J. E.; Jordan, M. J. T.; Perera, S. A.; Bartlett, R. J. Vibrational effects on the F-F spinspin coupling constant $\left({ }^{2 \mathrm{~h}} J_{\mathrm{F}-\mathrm{F}}\right)$ in $\mathrm{FHF}^{-}$and $\mathrm{FDF}^{-}$. J. Phys. Chem. A 2001, 105, 8399-8402.

34. Del Bene, J. E.; Perera, S. A.; Bartlett, R. J. ${ }^{15} \mathrm{~N},{ }^{15} \mathrm{~N}$ spin-spin coupling constants across N-H-N and $\mathrm{N}-\mathrm{H}^{+}-\mathrm{N}$ hydrogen bonds: Can coupling constants provide reliable estimates of $\mathrm{N}-\mathrm{N}$ distances in biomolecules? Magn. Reson. Chem. 2001, 39, S109-S114.

35. Del Bene, J. E.; Jordan, M. J. T. What a difference a decade makes: progress in $a b$ initio studies of the hydrogen bond. THEOCHEM, 2001, 573, 11-23.

36. Del Bene, J. E.; Perera, S. A.; Bartlett, R. J.; Elguero, J.; Alkorta, I.; López-Leonardo, C.; Alajarín, M. ${ }^{3 \mathrm{~h}} J\left({ }^{15} \mathrm{~N}-{ }^{31} \mathrm{P}\right)$ spin-spin coupling constants across $\mathrm{N}-\mathrm{H} \cdots \mathrm{O}-\mathrm{P}$ hydrogen bonds. J. Am. Chem. Soc. 2002, 124, 6393.

37. Peralta, J. E.; Ruiz de Azua, M. C.; Contreras, R. H. Natural bond orbitals analysis of C-H...O interactions in $\mathrm{NCH} / \mathrm{H}_{2} \mathrm{O}$ and $\mathrm{NCH} / \mathrm{OCH}_{2}$, and their effect on nuclear magnetic shielding constants. THEOCHEM, 1999, 491, 23-31.

38. Peralta, J. E.; Contreras, R. H.; Snyder, J. P. Natural bond orbital dissection of fluorine-fluorine through-space NMR coupling $(J \mathrm{~F}, \mathrm{~F})$ in polycyclic organic molecules. Chem. Commun. 2000, 2025-2026

39. Wilkens, S. J.; Westler, W. M.; Markley, J. L.; Weinhold, F. Natural J-coupling analysis: Interpretation of scalar J-couplings in terms of Natural Bond Orbitals. J. Am. Chem. Soc. 2001, $123,12026-12036$.

40. Arnold, W. D.; Mao, J.; Sun, H.; Oldfield, E. Computation of through-space ${ }^{19} \mathrm{~F}_{-}{ }^{19} \mathrm{~F}$ scalar couplings via Density Functional Theory. J. Am. Chem. Soc. 2000, 122, 12164-12168.

41. Arnold, W. D.; Oldfield, E. The chemical nature of hydrogen bonding in proteins via NMR: $J$ couplings, chemical shifts, and AIM Theory. J. Am. Chem. Soc. 2000, 122, 12835-12841.

42. Del Bene, J. E.; Perera, S. A.; Bartlett, R. J.; Alkorta, I.; Elguero, J.; Mó, O.; Yáñez, M. Onebond $\left({ }^{1 \mathrm{~d}} J_{\mathrm{H}-\mathrm{H}}\right)$ and three-bond $\left({ }^{3 \mathrm{~d}} J_{\mathrm{X}-\mathrm{M}}\right)$ spin-spin coupling constants across $\mathrm{X}-\mathrm{H} \cdots \mathrm{H}-\mathrm{M}$ dihydrogen bonds, J. Am. Chem. Soc., submitted.

43. Pecul, M. The nuclear spin-spin coupling constant in $\mathrm{He}_{2}$. J. Chem. Phys. 2000, 113, 1083510836.

44. Pecul, M.; Sadlej, J.; Leszczynski, J. The ${ }^{19} \mathrm{~F}-{ }^{1} \mathrm{H}$ coupling constants transmitted through covalent, hydrogen bond, and van der Waals interactions. J. Chem. Phys. 2001, 115, 5498-5506.

45. Bryce, D. L.; Wasylishen, R. E. Ab initio characterization of through-space indirect nuclear spin- 
spin coupling tensors for fluorine-X (X = F, C, H) spin pairs. J. Mol. Struct. 2002, 602-603, 463472.

46. Bagno, A.; Saielli, G.; Scorrano, G. DFT calculation of intermolecular nuclear spin-spin coupling in van der Waals dimers. Angew. Chem., Int. Ed. 2001, 40, 2532-2534.

47. Alkorta, I.; Rozas, I.; Jimeno, M. L.; Elguero, J. A theoretical and experimental study of the interaction of $\mathrm{C}_{6} \mathrm{~F}_{6}$ with electron donors. Struct. Chem. 2001, 12, 459-464.

48. Bagno, A.; Saielli, G.; Scorrano, G. Through-space spin-spin couplings in van der Waals dimers and $\mathrm{CH} / \pi$ interacting systems. An ab initio study. Chem. Eur. J. 2002, 8, 2047-2056.

49. Bagno, A.; Saielli, G.; Scorrano, G. Substituent effects on the through-space nuclear magnetic spin-spin coupling in van der Waals dimers. ARKIVOC, 2002, in press.

50. Mallory, F. B.; Mallory, C. W.; Butler, K. E.; Lewis, M. B.; Xia, A. Q.; Luzik, E. D.; Fredenburgh, L. E.; Ramanjulu, M. M.; Van, Q. N.; Francl, M. M.; Freed, D. A.; Wray, C. C.; Hann, C.; Nerz-Stormes, M.; Carroll, P. J.; Chirlian, L. E. Nuclear spin-spin coupling via nonbonded interactions. 8. The distance dependence of through-space fluorine-fluorine coupling. J. Am. Chem. Soc. 2000, 122, 4108-4116.

51. Alkorta, I.; Rozas, I.; Elguero, J. Non-conventional hydrogen bonds. Chem. Soc. Rev. 1998, 27, 163-170.

52. Rozas, I.; Alkorta, I.; Elguero, J. Inverse hydrogen-bonded complexes. J. Phys. Chem. A 1997, $101,4236-4244$.

53. Rozas, I.; Alkorta, I.; Elguero, Bifurcated hydrogen bonds: three-centered interactions. J. Phys. Chem. A 1998, 102, 9925-9932.

54. Alkorta, I.; Rozas, I.; Elguero, J. Charge-transfer complexes between dihalogen compounds and electron donors. J. Phys. Chem. A 1998, 102, 9278-9285.

55. Rowbotham, J. B.; Smith, M.; Schaeffer, T. Stereospecific spin-spin coupling between hydroxyl protons and ${ }^{19} \mathrm{~F}$ nuclei in $o$-, $m$ - and $p$-fluorophenyl derivatives. "Through-space" interactions via the hydrogen bond. Can. J. Chem. 1975, 53, 986-992.

56. Golubev, N. S.; Shenderovich, I. G.; Smirnov, S. N.; Denisov, G. S.; Limbach, H.-H. Nuclear scalar spin-spin coupling reveals novel properties of low-barrier hydrogen bonds in a polar environment. Chem.-Eur. J. 1999, 5, 492-497.

57. Shenderovich, I. G.; Burtsev, A. P.; Denisov, G. S.; Golubev, N. S.; Limbach, H.-H. Influence of the temperature-dependent dielectric constant on the H/D isotope effects on the NMR chemical shifts and the hydrogen bond geometry of the collidine-HF complex in $\mathrm{CDCl}_{3} / \mathrm{CDClF}_{2}$ solution. Magn. Reson. Chem. 2001, 39, S91-S99.

58. Smirnov, S. N.; Golubev, N. S.; Denisov, G. S.; Benedict, H.; Schah-Mohammedi, P.; Limbach, H.-H. Hydrogen/deuterium isotope effects on the NMR chemical shifts and geometries of intermolecular low-barrier hydrogen-bonded complexes. J. Am. Chem. Soc. 1996, 118, 40944101.

59. Schah-Mohammedi, P.; Shenderovich, I. G.; Detering, C.; Limbach, H.-H.; Tolstoy, P. M.; Smirnov, S. N.; Denisov, G. S.; Golubev, N. S. Hydrogen/deuterium isotope effects on the NMR 
chemical shifts and symmetry of homoconjugated hydrogen-bonded ions in polar solution. J. Am. Chem. Soc. 2000, 122, 12878-12879.

60. Dingley, A. J.; Grzesiek, S. Direct observation of hydrogen bonds in nucleic acid base pairs by internucleotide ${ }^{2} J_{\mathrm{NN}}$ couplings. J. Am. Chem. Soc. 1998, 120, 8293-8297.

61. Pervushin, K.; Ono, A.; Fernández, C.; Szyperski, T.; Kainosho, M.; Wütrich, K. NMR scalar couplings across Watson-Crick base pair hydrogen bonds in DNA observed by transverse relaxation-optimized spectroscopy. Proc. Natl. Acad. Sci. USA 1998, 95, 14147-14151.

62. Wöhnert, J.; Dingley, A. J.; Stoldt, M.; Görlach, M.; Grzesiek, S.; Brown, L. R.; Direct identification of $\mathrm{NH} \cdots \mathrm{N}$ hydrogen bonds in non-canonical base pairs of RNA by NMR spectroscopy. Nucleic Acid. Res. 1999, 27, 3104-3110.

63. Majumdar, A.; Kettani, A.; Skripkin, E. Observation and measurement of internucleotide ${ }^{2} J_{\mathrm{NN}}$ coupling constants between ${ }^{15} \mathrm{~N}$ nuclei with widely separated chemical shifts. J. Biomol. NMR 1999, 14, 67-70.

64. Hennig, M.; Williamson, J. R. Detection of $\mathrm{N}-\mathrm{H} \cdots \mathrm{N}$ hydrogen bonding in RNA via scalar couplings in the absence of observable imino proton resonances. Nucleic Acids Res. 2000, 28, 1585-1593.

65. Pervushin, K.; Fernández, C.; Riek, R.; Ono, A.; Kainosho, M.; Wütrich, K. Determination of ${ }^{\mathrm{h} 2} J_{\mathrm{NN}}$ and ${ }^{\mathrm{h} 1} J_{\mathrm{HN}}$ coupling constants across Watson-Crick base pairs in the Antennapedia homeodomain-DNA complex using TROSY. J. Biomol. NMR 2000, 16, 39-46.

66. Kojima, C.; Ono, A.; Kainosho, M. Studies of physicochemical properties of N-HYN hydrogen bonds in DNA, using selective ${ }^{15} \mathrm{~N}$-labeling and direct ${ }^{15} \mathrm{~N}$ 1D NMR. J. Biomol. NMR, 2000, 18, 269-277.

67. Bytchenkoff, D.; Chiarparin, E.; Früh, D.; Rüdisser, S.; Bodenhausen, G. Temperature dependence of internucleotide nitrogen-nitrogen scalar couplings in RNA. Magn. Reson. Chem. 2002, 40, 377-379.

68. Dingley, A. J.; Masse, J. E.; Feigon, J.; Grzesiek, S. Characterization of the hydrogen bond network in guanosine quartets by internucleotide ${ }^{3 \mathrm{~h}} J_{\mathrm{NC}^{\prime}}$ and ${ }^{2 \mathrm{~h}} J_{\mathrm{NN}}$ scalar couplings. J. Biomol. NMR 2000, 16, 279-289.

69. Kettani, A.; Gorin, A.; Majumdar, A.; Hermann, T.; Skripkin, E.; Zhao, H.; Jones, R.; Patel, D. J. A dimeric DNA interface stabilized by stacked A.(G.G.G.G).A hexads and coordinated monovalent cations. J. Mol. Biol. 2000, 297, 627-644.

70. Pervushin, K. The use of TROSY for detection and suppression of conformational exchange NMR line broadening in biological macromolecules. J. Biomol. NMR 2001, 20, 275-285.

71. Ishikawa, R.; Kojima, C.; Ono, A.; Kainosho, M. Developing model systems for the NMR study of substituent effects on the $\mathrm{N}-\mathrm{H} \cdots \mathrm{N}$ hydrogen bond in duplex DNA. Magn. Reson. Chem. 2001, 39, S159-S165.

72. Majumdar, A. Applications of ${ }^{1} \mathrm{H}_{\mathrm{a}^{-}}{ }^{1} \mathrm{H}_{\mathrm{b}}$ correlated ${ }^{2 \mathrm{~h}} J(\mathrm{~N}, \mathrm{~N})$ spectroscopy for identifying $\mathrm{H}_{\mathrm{a}}-\mathrm{C}-$ $\mathrm{N}_{\mathrm{a}} \cdots \mathrm{H}_{\mathrm{d}}-\mathrm{N}_{\mathrm{d}}$ hydrogen bonds in nucleic acids. Magn. Reson. Chem. 2001, 39, S166-S170.

73. Claramunt, R. M.; Sanz, D.; Alarcón, S. H.; Pérez Torralba, M.; Elguero, J.; Foces-Foces, C.; Pietrzak, M.; Langer, U.; Limbach, H.-H. 6-Aminofulvene-1-aldimine: A model molecule for the 
study of intramolecular hydrogen bonds. Angew. Chem. Int. Ed. 2001, 40, 420-423.

74. Pietrzak, M.; Limbach, H.-H.; Pérez-Torralba, M.; Sanz, D.; Claramunt, R. M.; Elguero, J. Scalar coupling constants across the intramolecular NHN hydrogen bond of symmetrically and nonsymmetrically substituted 6-aminofulvene-1-aldimines. Magn. Reson. Chem. 2001, 39, S100S108.

75. Sanz, D.; Pérez Torralba, M.; Alarcón, S. H.; Claramunt, R. M.; Foces-Foces, C.; Elguero, J. Tautomerism in the solid state and in solution of a series of 6-aminofulvene-1-aldimines. J. Org. Chem. 2002, 67, 1462-1471.

76. Rae, I. D.; Weigold, J. A.; Contreras, R. H.; Biekofsky, R. R. Analysis of long-range throughspace couplings via an intramolecular hydrogen bond. Magn. Reson. Chem. 1993, 31, 836-840.

77. Schaefer, T.; Wildman, T. A.; Salman, S. R. The perpendicular conformation of 2hydroxythiophenol. Intramolecular hydrogen bonding to specific lone pair. J. Am. Chem. Soc. 1980, 102, 107-110.

78. Anet, F. A. L.; Bourn, A. J. R.; Carter, P.; Winstein, S. Effect of steric compression on coupling constants. J. Am. Chem. Soc. 1965, 87, 5249-5250.

79. Schaeffer, T.; Chum, K. Spin-spin coupling between proximate protons on neighbouring aromatic rings and between hydroxyl protons in 2,2'-dihydroxy-4-methoxybenzophenone. Coupling through the hydrogen bond. Can. J. Chem. 1976, 54, 2231-2242.

80. Cordier, F.; Grzesiek, S. Direct observation of hydrogen bonds in proteins by interresidue ${ }^{3 \mathrm{~h}} J_{\mathrm{NC}}$ scalar couplings. J. Am. Chem. Soc. 1999, 121, 1601-1602.

81. Cornilescu, G.; Hu, J.-S.; Bax, A. Identification of the hydrogen bonding network in a protein by scalar couplings. J. Am. Chem. Soc. 1999, 121, 2949-2950.

82. Cordier, F.; Rogowski, M.; Grzesiek, S.; Bax, A. Observation of through-hydrogen-bond ${ }^{2 \mathrm{~h}} J_{\mathrm{HC}^{\prime}}$ in a perdeuterated protein. J. Magn. Reson. 1999, 140, 510-512.

83. Cornilescu, G.; Ramirez, B. E.; Franck, M. K.; Clore, G. M.; Gronenborn, A. M.; Bax, A. Correlation between ${ }^{3 h} J_{\mathrm{NC}^{\prime}}$ and hydrogen bond length in proteins. J. Am. Chem. Soc. 1999, 121, 6275-6279.

84. Wang, Y.-X.; Jacob, J.; Cordier, F.; Wingfield, P.; Stahl, S. J.; Lee-Huang, S.; Torchia, D.; Grzesiek, S.; Bax, A. Measurement of ${ }^{3 \mathrm{~h}} \mathrm{~J}_{\mathrm{NC}^{\prime}}$ connectivities across hydrogen bonds in a $30 \mathrm{kDa}$ protein. J. Biomol. NMR 1999, 14, 181-184.

85. Meissner, A.; Sørensen, O. W. New techniques for the measurement of $\mathrm{C}^{\prime} \mathrm{N}$ and $\mathrm{C}^{\prime} \mathrm{H}^{\mathrm{N}} J$ coupling constants across hydrogen bonds in proteins. J. Magn. Reson. 2000, 143, 387-390.

86. Meissner, A.; Sørensen, O. W. ${ }^{3 \mathrm{~h}} \mathrm{~J}$ Coupling between $\mathrm{C}^{\mathrm{a}}$ and $\mathrm{H}^{\mathrm{N}}$ across hydrogen bonds in proteins. J. Magn. Reson. 2000, 143, 431-434.

87. Cordier, F.; Wang, C.; Grzesiek, S.; Nicholson, L. K. Ligand-induced strain in hydrogen bonds of the c-Src SH3 domain detected by NMR. J. Mol. Biol. 2000, 304, 497-505.

88. Li, H.; Yamada, H.; Akasaka, K.; Gronenborn, A. M. Pressure alters electronic orbital overlap in hydrogen bonds. J. Biomol. NMR 2000, 18, 207-216.

89. Jaravine, V. A.; Alexandrescu, A. T.; Grzesiek, S. Observation of the closing of individual hydrogen bonds during TFE-induced helix formation in a peptide. Protein Sci. 2001, 10, 943- 
950.

90. Alexandrescu, A. T.; Snyder, D. R.; Abilgaard, F. NMR of hydrogen bonding in cold shock protein $\mathrm{A}$ and an analysis of crystallographic resolution on comparisons of hydrogen bond lengths. Protein Sci. 2001, 10, 1856-1868.

91. Hennig, M.; Geierstanger, B. H. Direct detection of a histidine-histidine side chain hydrogen bond important for folding of apomyoglobin. J. Am. Chem. Soc. 1999, 121, 5123-5126.

92. M. Pietrzak, J. Wehling, H.-H. Limbach, N. S. Golubev, C. López, R. M. Claramunt, J. Elguero. ${ }^{13} \mathrm{C}$ detected scalar nitrogen-nitrogen couplings across the intramolecular symmetric NHN hydrogen bond of proton sponges. J. Am. Chem. Soc. 2001, 123, 4338-4339.

93. Brown, S. P.; Pérez-Torralba, M.; Sanz, D.; Claramunt, R. M.; Emsley, L. The Direct Detection of a Hydrogen Bond in the Solid State by NMR through the Observation of a Hydrogen-Bond Mediated ${ }^{15} \mathrm{~N}-{ }^{15} \mathrm{~N} J$ Coupling. J. Am. Chem. Soc., 2002, 124, 1152-1153.

94. Mishima, M.; Hatanaka, M.; Yokoyama, S.; Ikegami, T.; Wälchli, M.; Ito, Y.; Shirakawa, M. Intermolecular ${ }^{31} \mathrm{P}_{-}{ }^{15} \mathrm{~N}$ and ${ }^{31} \mathrm{P}-{ }^{1} \mathrm{H}$ scalar couplings across hydrogen bonds formed between a protein and a nucleotide. J. Am. Chem. Soc. 2000, 122, 5883-5884.

95. Löhr, F.; Mayhew, S. G.; Rütterjans, H. Detection of scalar couplings across NH‥OP and OH...OP hydrogen bonds in a flavoprotein. J. Am. Chem. Soc. 2000, 122, 9289-9295.

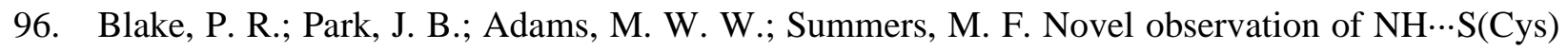
hydrogen-bond-mediated scalar coupling in cadmium-113 substituted rubredoxin from Pyrococcus furiosus. J. Am. Chem. Soc. 1992, 114, 4931-4933.

97. Blake, P. R.; Lee, B.; Summers, M. F.; Adams, M. W. W.; Park, J. B.; Zhou, Z. H.; Bax, A. Quantitative measurement of small through-hydrogen-bond and 'through-space' proton-cadmium113 and proton-mercury-199 $J$ couplings in metal-substituted rubredoxin from Pyrococcus furiosus. J. Biomol. NMR 1992, 2, 527-533.

98. Platzer, N.; Buisson, J.-P.; Demerseman, P. Complete ${ }^{1} \mathrm{H}$ and ${ }^{13} \mathrm{C}$ NMR spectral characterization of 1,6-dioxapyrene and related compounds. An unusual coupling interaction through hydrogen bond in three precursors. J. Heterocyl. Chem. 1992, 29, 1149-1153.

99. Kwon, O.; Danishefsky, S. J. Synthesis of asialo $\mathrm{GM}_{1}$. New insights in the application of sulfonamidoglycosylation in oligosaccharide assembly: subtle proximity effects in the stereochemical governance of glycosidation. J. Am. Chem. Soc. 1998, 120, 1588-1599.

100. Laynez, J.; Menéndez, M.; Saiz, J. L.; Llamas-Saiz, A. L.; Foces-Foces, C.; Elguero, J.; Molina, P.; Alajarín, M.; Vidal, A. Iminophosphorane-substituted proton sponges. Part 4. Comparison of $\mathrm{X}$-ray molecular structures with solution properties ( $\mathrm{p} K \mathrm{a},{ }^{1} \mathrm{H}$ and ${ }^{13} \mathrm{C}$ NMR spectroscopy). $J$. Chem. Soc., Perkin Trans. 2 1993, 709.

101. Elguero, J.; Fruchier, A.; Jimeno, M. L.; Molina, P. An experimental study of the ${ }^{4 h} J\left({ }^{31} \mathrm{P}_{-}{ }^{31} \mathrm{P}\right)$ coupling constant and the ${ }^{12} \mathrm{C} /{ }^{13} \mathrm{C}$ isotope effect on ${ }^{31} \mathrm{P}$ in an iminophosphorane-substituted proton sponge. J. Chem. Res. (S) 2002, 34-36.

102. Majumdar, A.; Kettani, A.; Skripkin, E.; Ptel, D. J. Observation of internucleotide NH $\cdots \mathrm{N}$ hydrogen bonds in the absence of directly detectable protons. J. Biomol. NMR 1999, 15, 207-211.

103. Liu, A.; Majumdar, A.; Hu, W.; Kettani, A.; Skripkin, E.; Patel, D. J. NMR detection of N- 
$\mathrm{H} \cdots \mathrm{O}=\mathrm{C}$ hydrogen bonds in ${ }^{13} \mathrm{C},{ }^{15} \mathrm{~N}$-Labeled Nucleic Acids. J. Am. Chem. Soc. 2000, 122, 32063210 .

\section{General Sources}

Density Functional Methods in Chemistry (Lebanowski, A.; Andzelm, J. Eds.), Springer, N.Y. 1991.

Modern Density Functional Theory: A Tool for Chemists (Seminario, J. M.; Politzer, P. Eds.), Elsevier, Amsterdam, 1995, Vol. 2.

Theoretical Treatments of Hydrogen Bonding (Hadzi, D. Ed.), Wiley \& Sons, N.Y. 1997.

Electronic Density Functional Theory: Recent Progress and New Directions (Dobson, J. F.; Vignale, G.; Das, M. P., Eds.), Plenum Press, N.Y. 1998.

Contreras, R. H.; Peralta, J. E. Angular dependence of spin-spin coupling constants. Prog. Nucl. Magn. Reson. Spectrosc. 2000, 37, 321-425.

Contreras, R. H.; Peralta, J. E.; Giribet, C. G.; Ruiz de Azua, M. C.; Facelli, J. C. Advances in theoretical and physical aspects of spin-spin coupling constants. Annu. Rep. NMR Spectrosc. 2000, $41,55-184$.

Pervushin, K. Impact of transverse relaxation optimized spectroscopy (TROSY) on NMR as a technique in structural biology. Q. Rev. Biophys. 2000, 33, 161-197.

Koch, W.; Holthausen, M. C. A Chemist's Guide to Density Functional Theory, 2nd Edition, WileyVICH, 2001.

Grzesiek, S.; Cordier, F.; Dingley, A. J. Scalar couplings across hydrogen bonds. Methods Enzymol. 2001, 338, 111-133.

Dingley, A. J.; Cordier, F.; Grzesiek, S. An introduction to hydrogen bond scalar couplings. Concepts Magn. Reson. 2001, 13, 103-127.

Majumdar, A.; Patel, D. J. Identifying Hydrogen Bond Alignments in Multistranded DNA Architectures by NMR. Acc. Chem. Res. 35, 1-11 (2002).

(C) 2003 by MDPI (http://www.mdpi.org). Reproduction for noncommercial purposes permitted. 